\title{
Title: Cellular Effects of Cylindrospermopsin (Cyanobacterial Alkaloid Toxin) and its Potential Medical Consequences
}

\begin{abstract}
Cylindrospermopsin (CYN) is a tricyclic guanidino derivative, an alkaloid toxin produced by several cyanobacterial genera. It alters cellular functioning in eukaryotes, including animal and plant organisms. Over the past decades, more and more evidence shows its potential hazardous effects on animal and human health. In this review, we give a critical survey and interpretation of data currently available on its biochemical and consequently, cellular effects. CYN is considered to be a cytotoxin. Several reports suggest that it is a potent inhibitor of eukaryotic protein synthesis, though the exact mechanisms are far from not completely understood. Here we show that the biochemical changes induced by CYN suggest are complex, and possibly involving multiple modes of action. Glutathione metabolism and pyrimidine nucleotide synthesis is affected besides the proposed protein synthesis inhibition. Biochemical alterations lead to the following cellular/subcellular alterations both in animals and plants: (i) changes in cell division rates due to perturbations in chromatin and cytoskeleton; (ii) perturbations of structure and functioning of endomembranes including endoplasmic reticulum; (iii) general metabolic alterations leading to genotoxicity and programmed cell death/apoptosis. The underlying mechanisms and possible health consequences are discussed.
\end{abstract}

Keywords: cylindrospermopsin, cyanobacteria, protein synthesis, cell cycle, endomembranes, cytoskeleton, programmed cell death

\section{INTRODUCTION}

Cylindrospermopsin (CYN) is a highly water soluble cyanobacterial polyketide-derived alkaloid. Its chemical structure was proposed for the first time in 1992 by Othani [1]. In the sulphated CYN $\left(\mathrm{C}_{15} \mathrm{H}_{21} \mathrm{~N}_{5} \mathrm{O}_{7} \mathrm{~S}\right)$ molecule $(\mathrm{m} / \mathrm{z}$ of 416) a central functional guanidino moiety combined with hydroxymethyluracil is attached to its tricyclic carbon skeleton (Fig. 1). The occurrence of natural CYN analogs- of 7-epi-CYN (an epimer at the hydroxyl bridge) and 7-deoxyCYN (lacking the hydroxyl group) has also been recently identified from cyanobacterial strains [2,3] (Fig. 1).

To date, thirteen filamentous cyanobacterial species have been reported as potent producers of this alkaloid toxin: Cylindrospermopsis raciborskii [1], Aphanizomenon ovalisporum (currently Chrysosporum ovalisporum) [4], Aphanizomenon flos-aquae [5], Aphanizomenon gracile [6] and [7], Aphanizomenon klebahnii [8], Umezakia natans [9], Raphidiopsis curvata [10], Raphidiopsis mediterranea [11], Anabaena bergii [12], Anabaena planctonica [13], Anabaena lapponica [14], Lyngbya wollei [3] and at least several strains of Oscillatoria sp. [15].

Structural organization of the cylindrospermopsin gene cluster, encoding all the functions required for the biosynthesis, regulation and export of the toxin from $C$. raciborskii AWT205 is clarified by Mihali et al. [16]. The steps of biosynthesis of the molecule seem to be elucidated as well, involving a novel pyrimidine biosynthesis mechanism of uracil ring formation [16-20]. The formation of the carbon skeleton of CYN involves the synthesis of guanidinoacetate and uracil rings and seems does not appear to be in competition rivaling with the synthesis of purine or pyrimidine bases in $\mathrm{CYN}$ producing organisms.

Fig. (1). The chemical structure of CYN and its natural analogs. Designation of (A, B, C) rings is according to Runnegar et al. [21].

CYN was detected in recreational waters, in some reservoirs used for supplying drinking water [22, 23]. It and has been documented as being involved in at least two epidemic cases of human poisoning [24, 25]. It has several toxic effects: dermatotoxicity, cytotoxicity, genotoxicity and in animals and humans organisms, the liver may be the primary target [26, 27]. Its worldwide occurrence in freshwaters raises the probability of its interference with ecosystem integrity, affecting both animal and plant organisms [27, 28]. A broad range of experimental in vivo and in vitro studies focusing on CYN toxicity on several animal and plant organisms was performed-It has been showing to interference with a wide variety of eukaryotic metabolic pathways $([26,29]$ and see section 2 of this review).

For the above reasons, understanding CYN action at the cellular level is of crucial importance. For studying the cellular events induced by CYN, an important question is: after entry to the cell, what are will be its subcellular localization(s)? Work like that of Elliott et al. [30] made possible the development of poly-and monoclonal antibodies to CYN and paved the way for such studies. Histological analysis showed that liver tissues of tilapia fish were the most responsive for CYN immunolabeling, and that kidney, intestine and gills showed the presence of the cyanotoxin as 
well. For cells of this organism, the most intense labeling occurred in the cytoplasm with characteristic CYN signal around the nucleus [31, 32]. Since the primary goal of these studies was the detection of the cyanotoxin at the histological level, there are no do not have data on higher resolution subcellular localization of CYN. Thus, here we review the present knowledge on the cellular effects of CYN. however, Better knowledge of its subcellular localization in toxin treated tissues will certainly contribute to a better understanding of its cytotoxicity.

The principal objective of this review is to show the main cellular effects of CYN in eukaryotes including plants. These effects will be grouped into three sections- changes in cell cycle including the related chromatin and cytoskeletal alterations, effects on the endomembrane system including alterations in the organization of ER and Golgi apparatus and the induction of programmed cell death (PCD) by CYN. The main cellular alterations induced will be summarized in Table 1. Finally, we will present the main conclusions regarding the molecular effects of CYN in the light of cellular changes induced.

\section{OVERVIEW OF THE MOLECULAR EFFECTS OF CYN}

The excellent reviews of Žegura et al. [26] and Poniedziałek et al. [33] pointed out the main mechanisms of CYN toxicity at the molecular/biochemical level. According to the current knowledge, these are (A) rapid toxicity mediated by cytochrome monooxygenase P450 (CYP450) generated metabolites (see also [21, 34, 35]). although This type of mechanism was not proven to be universal in eukaryotes. For example, Kittler et al. [36] could not detect phase I metabolites of CYN in HepaRG cells. When cultured mouse hepatocytes were treated with CYP450 inhibitors together with CYN, lactate dehydrogenase leakage was significantly attenuated as compared to CYN-only treatments [37]; (B) long-term toxicity mechanisms that include (i) the inhibition of eukaryotic protein synthesis; (ii) inhibition of glutathione synthesis; (iii) inhibition of pyrimidine nucleotide synthesis (see also [38]); (iv) CYN may interfere with eukaryotic DNA synthesis and transcription (see also [39]). In this section we will give a short critical overview on the inhibition of protein, glutathione and pyrimidine nucleotide synthesis, since these three biochemical events may be responsible for the most cytotoxic effects of CYN.

\subsection{The inhibition of eukaryotic protein synthesis}

Terao et al. [40] established the four main phases of CYN induced cell death events in liver cells of CYN treated mice: (1.) inhibition of protein synthesis, (2.) stimulation of the formation of intracellular membrane systems membrane proliferation, (3.) fat droplet accumulation and (4.) cell death. The inhibition of protein synthesis was pointed to as the initial phase of the successive changes. When they compared electronmicrographs of liver and kidney of CYN treated mice with the protein synthesis inhibitory cycloheximide (CHM) treated ones, similarities (dissociated ribosomes, formation of fat droplets) and differences (increased areas of fat droplets, abundance proliferation of intracellular membrane systems- SER, Golgi, vacuoles, were induced only by CYN) were described as well. However, the complex ultrastructural changes similar to those induced by $\mathrm{CHM}$ could be the consequences of not only protein synthesis inhibition, but to other unknown mechanism, too. This issue needs further research. Protein synthesis inhibitory effects of CYN were supported by diminished protein and CYP450 content in hepatic microsomes of CYN treated livers. Because globin synthesis measured in vitro in a rabbit reticulocyte cell-free system was completely inhibited by CYN (48 $\mathrm{ng} \mathrm{mL}-1$ ), they could establish "that one of the direct effects of CYN must be based on its potent inhibitory effects on protein synthesis in various cell types" [40]. They did not exclude the existence of other mechanisms, accumulation of free radicals being possibly responsible for some detected cellular alterations (abundance of intracellular membranes proliferation, accumulation of fat droplets, proximal convoluted urinary tubules) [40].

Froscio et al. [41] described a rabbit reticulocyte lysate translation system as an accurate and rapid assay for the measurement of CYN content in cyanobacterial extracts. A dose response curve for protein synthesis inhibition by CYN was constructed. This protein synthesis inhibition assay with $\mathrm{IC}_{50}$ : $120 \mathrm{nM}$ has a detection limit of $50 \mathrm{nM} / 20.8 \mu \mathrm{g} \mathrm{L}^{-1}$ $\mathrm{CYN}$ in an assay solution. Significant, concentration dependent (1-5 $\left.\mu \mathrm{M} / 0.416-2 \mu \mathrm{g} \mathrm{mL} \mathrm{m}^{-1}\right)$ toxicity was detected at $18 \mathrm{~h}$ exposure to $\mathrm{CYN}$ of a primary mouse hepatocyte culture, where the inhibition of protein synthesis was a sensitive, early indicator of cell responses. Inhibition of CYP450 diminished CYN induced cell toxicity, but not the effect on protein synthesis [35]. Authors distinguished CYN caused protein-synthesis inhibition from the acute toxicity of CYN through CYP450.

Runnegar et al. [21] used the results of CYN and epiCYN synthesis [42, 43] and compared the biological activity of naturat CYN to its synthetic analogues and intermediates. Protein synthesis at the level of translation was measured in vitro using a rabbit reticulocyte lysate system, in which incorporation of $\left[\mathrm{S}^{35}\right]$ methionine into luciferase was counted. and In vivo study used primary cultures of rat hepatocytes as intact cells, in which the incorporation of $\left[\mathrm{S}^{35}\right]$ methionine to protein fraction of hepatocytes during incubation was detected. The concentration dependent inhibitory effects of natural and synthetic CYN ("RAC-CY") and other analogues ("CY-DIOL, EPI-CY, EPI-DIOL") on protein-synthesis were elucidated proven in both systems. For natural $\mathrm{CYN}$ the in vitro and in vivo $\mathrm{IC}_{50}$ concentrations were: 0.21 and about $0.128 \mu \mathrm{M}\left(0.08\right.$ and $\left.0.05 \mu \mathrm{g} \mathrm{mL} \mathrm{mL}^{-1}\right)$ respectively. When they compared the above effects with those of intermediates, the most important conclusions were that neither sulphate group, nor orientation of the hydroxyl group at C-7 are necessary for the uptake of CYN into the cell and for protein synthesis inhibition, in contrast to the presence of $\mathrm{C}-7 \mathrm{OH}$-group. The importance of the AB-ring (see Fig. 1) for inhibition of protein synthesis was proven both in vivo and in vitro as well; synthetic AB-MODEL with 
lacking intact C-ring and methyl and hydroxyl groups on Aring could significantly inhibit protein synthesis at $\geq 100 \mu \mathrm{M}$ and $\geq 400 \mu \mathrm{M}$. They concluded, that intact C-ring and functionality of A-ring are important for efficient inhibition of translation by CYN [21]. It is known as well, that Beside hydroxyl group, uracil moiety is crucial for CYN toxicity [2].

Since 1994 the toxic mechanism of CYN has not been fully elucidated at the molecular level, but several studies indicated it became established that CYN inhibits directly protein synthesis, because inhibition of translation was reported using both in vivo and in vitro animal test systems by several researcher groups $[21,35$, $37,41,44]$.

Vasas et al. [45] were the first who reported proved that CYN can negatively influence the life of plants as well. CYN was investigated in different experimental systems to elucidate whether it inhibits protein synthesis in plants as well. Metcalf et al. [46] exposed tobacco (Nicotiana tabacum) pollen to CYN and detected the inhibition of pollen germination (pollen tube growth) with an $\mathrm{IC}_{50}$ of 300 $\mu \mathrm{g} \mathrm{mL}{ }^{-1} \mathrm{CYN}$ (high cyanotoxin concentration). In this in vitro toxicity test-system pollen tube growth and protein synthesis were investigated by Alcian Blue binding and the incorporation of radiolabelled L-leucine $/{ }^{14} \mathrm{C}(\mathrm{U})$-L-leucine/. At $138 \mu \mathrm{g} \mathrm{mL}^{-1} \mathrm{CYN}$ the incorporation of radiolabelled Lleucine showed higher quotients than the positive controls (using 20\% ethanol in water instead of CYN), but significantly lower than negative controls (using water instead of CYN). Researchers underlined that the relationship between the two detected changes (inhibited pollen tube growth and inhibited protein synthesis at translation level) was possibly indirect. It should be noted that CYN concentrations used to detect inhibitory effects were high in this study.

Froscio et al. [47] gave a probable explanation for the molecular mechanism of CYN induced protein synthesis inhibition. The eukaryotic protein synthesis apparatus was inhibited in plant and mammalian cell extracts with $\mathrm{IC}_{50}=$ $334 \mathrm{nM}$ for wheat germ extract and $110 \mathrm{nM}$ in reticulocyte lysate. The results were compared to CYN induced protein synthesis inhibition in E. coli extracts, in which $100 \mathrm{mM}$ CYN reduced protein synthesis by $25 \%$ [48]. Thus, the cyanotoxin had 1000-fold less activity on prokaryotic ribosomes/translation system than on eukaryotic ones [47]. Binding of $\left[{ }^{14} \mathrm{C}\right] \mathrm{CYN}$ to $80 \mathrm{~S}$ ribosomes and /or translation components was assessed in reticulocyte lysates. CYN could not bind covalently to ribosomes, because binding of $\left[{ }^{14} \mathrm{C}\right]$ CYN could be partially displaced by the addition of unlabelled toxin. The target of CYN may not be the intact ribosome itself, but rather one of the large MW ( $\geq 100 \mathrm{kDa})$ soluble proteins associated with the eukaryotic translation system.

The assay of de novo protein synthesis in white mustard (Sinapis alba) seedlings was carried out by measuring incorporation of ${ }^{35} \mathrm{~S}$-methionine/pulse labelling in order to see whether mitotic alterations induced by CYN are related to its effects on protein synthesis [49]. De novo protein synthesis of young roots underwent two cycles in the time frame analyzed, with maximal levels of protein synthesis at $15-16 \mathrm{~h}$ and 38-39 $\mathrm{h}$ after the start of pulse labeling. $18 \mu \mathrm{g} \mathrm{mL}^{-1} \mathrm{CYN}$ induces $50 \%$ growth inhibition of $S$. alba seedlings [45]. This cyanotoxin concentration delayed protein synthesis. In the first cycle, protein synthesis was inhibited as compared to control, with maximal values at 16-18 h, but in the second cycle, protein synthesis was stimulated, with maximal values at 39-40 h after the start of seed germination. Delayed de novo protein synthesis was accompanied with delayed mitotic activity in the time frame studied (43 h). It was concluded that one of the possible causes of mitotic changes induced by CYN is its protein synthesis delaying effect.

In spite of the promising findings of Froscio et al. [47] the detailed mechanism of protein synthesis inhibition by CYN is not known yet. Observations like that of Gutiérrez-Praena et al. [50]- induction of nucleolar segregation by CYN- could be one of the additional keys for elucidating this issue. General mechanisms of nucleolar segregation involve not only its disassembly at the beginning of mitosis, but might be induced by (i) binding of inhibitors like actinomycin D, an eukaryotic protein synthesis inhibitor, to the DNA core of nucleolus [51]; CYN might bind directly DNA due to its uracyl moiety, or (ii) oxidative stress induced formation of DNA adducts in the rDNA regions [52]. It is worth mentioning that in this respect, CYN acts differently to CHM, a well-known eukaryotic protein synthesis inhibitor that never induces nucleolar segregation [51].

In spite of both in vitro and in vivo evidence for CYN mediated protein synthesis inhibition, there are several data that challenge the general inhibitory effect hypothesis- and that the main mechanism of CYN cytotoxicity is the inhibition of protein synthesis: (i) in contrast to the decrease of protein content observed in several vertebrate cell types (see [53] for an example), CYN treated aquatic plants, including Wolffia arrhiza show slight increases in the content of total soluble proteins, even though the cyanotoxin induced significant increases of protease activities that could alter total protein pool [54]; (ii) several proteins show increased expression in certain animal and plant cell types treated with CYN $[28,55,56]$. The expression of proteins related to signal transduction or reactive oxygen species (ROS) scavenging was increased by $10-100 \mu \mathrm{g} \mathrm{L}^{-1} \mathrm{CYN}$ in HepG2 cells [57]. It should be noted that low CYN concentrations (up to $10 \mu \mathrm{g} \mathrm{L}^{-1}$ ) increased ROS levels, but stimulated metabolism and division in this cell line [58]. Freitas et al. [59] investigated the lettuce (Lactuca sativa L.) leaf-proteome profiles after exposure to CYN. The number of protein spots with increased intensity was higher than the number of spots with decreased intensity or lacking in CYN treated plants. When CYN was combined with microcystinLR (MCY-LR), a protein phosphatase inhibitory and ROS inducing cyanotoxin, this effect was more pronounced, but the highest protein number was characteristic at the lowest (1 $\left.\mu \mathrm{g} \mathrm{L}^{-1}\right) \mathrm{CYN}+\mathrm{MCY}-\mathrm{LR}$ concentration. A large number of identified proteins in both experiments (CYN only and CYN/MCY-LR combinations) are involved in photosynthesis and carbon metabolism, ATP synthesis, 
stress/defense response and protein folding. 1-100 $\mu \mathrm{g} \mathrm{\textrm {L } ^ { - 1 }}$ CYN combined with identical amounts of MCY-LR, increased the expression level of many cytosolic and chloroplast proteins involved in translation of lettuce proteins and signal transduction events- however, expression of several other proteins of this class decreased in the presence of 10-100 $\mu \mathrm{g} \mathrm{L}^{-1} \mathrm{CYN}$ [59]. (iii) Froscio [37] found no correlation between protein synthesis inhibition and the decrease of viability for cultured male Swiss Albino mouse hepatocytes. (iv) CYN up-regulated the transcription of most genes examined that were related to ribosome biogenesis in liver cells of pregnant mice [60]. The expression profiles were examined in mice treated i.p. with $50 \mu \mathrm{g} \mathrm{CYN} \mathrm{kg} \mathrm{bw}^{-1}$ for 5 days and showed alterations in the transcription of genes involved in ribosomal biogenesis beside other important genes of metabolism, stress responses involving oxidative stress. Interestingly, gene expression analysis indicated a down-regulation of Coagulation Factor $\mathrm{X}$. Chernoff et al. [60] underlined that deficiencies in the expression of this gene could have been associated with bleeding in both humans and mice. Straser et al. [61] performed toxicogenomic analysis of selected genes commonly affected by genotoxic stress in HepG2 cells exposed to low, "genotoxic concentration" of CYN (0.5 $\mu \mathrm{g}$ $\mathrm{mL}^{-1}$ ) for 12 and $24 \mathrm{~h}$. In the set of 190 selected genes commonly affected by genotoxic stress, both downregulated and induced ones were present considering the transcript levels, more genes being significantly upregulated. After 12 $\mathrm{h}$ of exposure to CYN, $31 \%$ of the selected genes were significantly modulated, but only $17 \%$ were modulated by more than 1.5-fold relative to non-treated control cells. After $24 \mathrm{~h}$ of exposure, $47 \%$ of the genes were significantly modulated and $30 \%$ were modulated more than 1.5 -fold. At 12 h 27 genes were upregulated while 7 downregulated, at $24 \mathrm{~h} 41$ were upregulated and only 22 repressed more than 1.5-fold. Several important genes in DNA-damage-repair, cell-cycle and genes of enzymes playing role in the detoxification response were upregulated [62]. However it is known that changes in the level of gene transcription do not mean automatically changes in protein levels.

Whether cytotoxicity of CYN is mediated in general by free cyanotoxin or by its modification via activators like CYP450- still remains a major question [37]. According to current knowledge, protein synthesis inhibition by itself is not the single metabolic alteration responsive for CYN toxicity (see next section).

\subsection{Effects on glutathione metabolism and the inhibition of pyrimidine nucleotide synthesis}

Runnegar and her colleagues reported proved that CYN induced cell death in primary rat hepatocyte cultures was preceded by the fall in GSH content of cells. Decrease of GSH pool of cells was the consequence of inhibited GSH synthesis and not the increase in GSH efflux or consumption as well as the formation of oxidized glutathione GSSG or GSH-conjugates $[21,63,64]$. The $\mathrm{IC}_{50}$ for natural $\mathrm{CYN}$ was $2.38 \mu \mathrm{M}\left(1 \mu \mathrm{g} \mathrm{mL} \mathrm{m}^{-1}\right)$. This concentration was higher, than the in vitro and in vivo protein synthesis inhibitory level
(0.21 and about $0.128 \mu \mathrm{M})$. The synthetic CYN analogue AB-MODEL inhibited protein synthesis, but was not effective in inhibition of GSH synthesis even at 250-500 $\mu \mathrm{M}$ [21].

CYN induced reduction in GSH synthesis was confirmed in several experimental systems- for example, in in vivo treated tilapia fish (Oreochromis niloticus, [53, 65] exposed to $200 \mu \mathrm{g} \mathrm{kg} \mathrm{kg}^{-1}$ pure $\mathrm{CYN}$ ) and in vitro in topminnow ( $P$. lucida) fish cell system. Decrease of cellular GSH level and activity of $\gamma$-glutamyl cysteine synthetase (GCS) [53, 65] was measured. Meanwhile, protein content of soluble (cytosolic) fraction of organs did not decrease. CYN induced changes in activity of GCS, the rate limiting enzyme in GSH synthesis, correlated with the tendency of GSH depletion. Both biomarkers showed a temporary decrease [65]. PLHC-1 cells derived from a hepatocellular carcinoma of topminnow were used as in vitro test and after a transient increase at $2 \mu \mathrm{g} \mathrm{mL}^{-1} \mathrm{CYN}$ exposure, at $8 \mu \mathrm{g} \mathrm{mL}^{-1} \mathrm{CYN}$ a significant decrease was measured in GSH content (after 10 min. of exposure to pure CYN) and in GCS activity (after 24 $\mathrm{h}$ of exposure to pure $\mathrm{CYN}$ ) as well [53]. One can assume that cells try to face this assault by increasing the production of GSH in order to minimize toxin induced damage. At exposures to higher cyanotoxin concentrations the significant depletion in GSH levels of cells could be the result of decreased synthesis, because GCS activity decreased following a similar pattern to that of GSH content reduction [53]. GSH content linked to the activity of GCS in vitro and in vivo proved that CYN induced fall in GSH is a consequence of inhibition of GSH synthesis [53, 65].

We will discuss further aspects of the interference of CYN with glutathione metabolism in the context of cyanotoxin induced oxidative stress and cell death (section 3.3. of this review).

Reisner et al. [38] investigated the effect of CYN on the in vitro activity of uridine monophosphate (UMP) synthase complex (responsible for the conversion of orotic acid to UMP) in a cell free liver extract from mice. They demonstrated that CYN inhibited in a noncompetitive manner the in vitro activity of this enzyme complex. If mice were exposed to $\mathrm{CYN}$ at subacute concentrations via drinking water, only slight effect on the in vitro activity of UMP synthase was measured. and The typical metabolic disorder associated with the inhibition of UMP synthase activity, known as "orotic aciduria," was not observed, but other anomalous metabolic responses related to cholesterol metabolism were detected. The authors concluded that due to the uracil moiety, CYN can competitively bind to catalytic site/s involved in the synthesis and transformation of pyrimidine nucleotides (i.e., uridine).

Thus, the long-term toxicity of CYN seems to be related mainly to irreversible inhibition of protein synthesis and inhibition of GSH synthesis [47, 64]. However, many studies challenge the protein synthesis inhibitory effect of CYN. Fall in GSH pool can lead to oxidative stress that alters several other metabolic pathways [29, 33, 66-68]. This issue will be discussed in detail in relation to $\mathrm{CYN}$ induced cellular alterations. 


\section{CELLULAR EFFECTS OF CYN}

\subsection{Effects on cell cycle and related chromatin and cytoskeletal organization}

The mitotic capacity of several human and animal cell types is significantly affected by CYN. Mitosis of human Tlymphocytes is severely inhibited, pointing out that the cyanotoxin may affect the immunogenic capacity of a lymphocyte population [69]. The molecular background of mitosis inhibition was supposed to be the activation of cyclin dependent kinase inhibitors (CDKIs) in this case. Indeed, CYN is able to increase the expression of a CDK inhibitor via the activation of p53 transcription factor [70]. For HepG2 cells, nuclear division index showed slight decreases in CYN treated cells, but no clear correlation could be found with the expression (transcription) of genes involved in the block of cell cycle [71]. However the same research team showed changes in the same experimental system in the transcription of genes involved in cell cycle regulation [61]. The most important changes were: (i) up-regulation of CDKN2B, a cyclin dependent kinase inhibitor (CDKI) that blocks G1/S transition at $12 \mathrm{~h}$ exposure to the cyanotoxin; (ii) upregulation of genes involved in blocking of G1/S and G2/M transition including gene products involved in DNA damage repair (e.g. CDKN1A- a CDKI, genes of the GADD family, E2F4) and decreased transcription of a cell cycle activator, cyclinG1. Further thoughts on this topic will be presented when we discuss the possible molecular mechanisms underlying CYN induced cell cycle changes (see below in this section). For CHO-K1 cells, chromatin condensation is blocked at early stages and both microtubule (MT) and microfilament (MF) organization is altered [72]. In accordance with this study, CYN inhibited mitotic activity in this cell type [73]. Decreases in the mitotic activity were observed for murine embryonic stem cells, when long-term treated with WHO guideline levels of CYN [74].

There is a relatively low number of studies concerning mitotic spindle alterations induced by CYN in animal/ human cells. However the early research performed by Humpage et al. [75] used micronucleus assays and the detection of centromeres, showing probable chromosome loss due to disruptions of spindle MT-kinetochore connections in a CYN treated lymphoblastoid cell line.

Concerning plants, the cell cycle alterations induced by CYN are only partially known. and To date, these studies concentrated mainly on mitotic activities of common reed (Phragmites australis) and broad bean (Vicia faba) root tip meristematic cells [28, 29, 49]. They studies can be summarized as follows: (i) mitotic activities depend largely on cyanotoxin exposure time. While there are only slight changes in mitotic indices at relatively short-term exposures, at long term CYN treatments (6 days for $V$. faba, a wellknown eukaryotic model and 10 days for Phragmites australis, an aquatic macrophyte), lower concentrations (0.1-
$5 \mu \mathrm{g} \mathrm{mL} \mathrm{m}^{-1}$, depending on the plant species studied) increased total mitotic index as well as the percentage of early and in case of $V$. faba of late mitotic cells. In case of $V$. faba, higher CYN concentrations $\left(\geq 5 \mu \mathrm{g} \mathrm{mL}^{-1}\right)$ inhibited cell division activity. (ii) in root tip cells synchronized in the $\mathrm{S}$ phase, $\mathrm{CYN}$ delayed the onset of mitosis. Further research is needed to establish whether mitosis itself (G2/M transition) is delayed, or this effect is due to perturbations in the onset of $\mathrm{S}$ phase. This late mitosis onset correlates well with the effects of CYN on de novo protein synthesis in higher plant seedlings, which was delayed rather than inhibited [49]. (iii) CYN induces characteristic changes in the organization of mitotic chromatin and microtubular (MT) cytoskeleton. The most prominent change is the formation of abnormal preprophase bands (PPBs). PPB is a cytoskeletal structure peculiar for plants and it has a crucial role in the establishing of cell division plane. Abnormal PPB formation will lead to perturbations in the orientation of mitotic spindle which can lead to abnormal organization of a whole tissue [76]. These anomalous structures are correlated with the inhibition of protein synthesis in general (see [77]), but they can be associated to the inhibition of auxin (a plant growth regulator) efflux as well [78]. Thus, protein synthesis inhibition is possibly not the sole cause of the formation of double, split or asymmetric PPBs. CYN induces the formation of other abnormal mitotic figures too- tripolar spindles, disorganized phragmoplasts (phragmoplast is a plant cytokinetic structure. It consists of MTs, microfilaments /MFs/ and trans-Golgi derived vesicles. It is formed at the plane of cell division and has an essential contribution to the building up of cell walls). The latter two alterations may induce the formation of lagging chromosomes [28]. We propose that alteration of the synthesis of microtubule associated proteins (MAPs), together with misorganization of microtubule organizing centers (MTOCs) is responsible for CYN induced alteration of mitotic MT structures [28].

(iv.) CYN induces chromosome breakage in higher plants, indicating its potential clastogenic effect on eukaryotic cells ([49] and see section 3.3. of this review). It should be noted however, that such cytogenetic disorders are not universally induced by CYN. Whole chromosome loss, but not individual chromosome breaks were detected in the human lymphoblastoid cell line WIL-2 NS [75].

(v.) Although this does not involve actively cycling cells, CYN induced the reorientation of cortical microtubules (CMTs). Meanwhile, the density of CMTs decreased dramatically in a similar way to MT system of CYN treated CHO-K1 cells (see [72]). For plants, normal orientation of CMTs is very important for the normal (anisotropic) growth of elongating/differentiating cells. A shift of CMT orientation from perpendicular to longitudinal with respect to the longitudinal axis of the plant body will inhibit longitudinal growth and promote abnormal, radial expansion of whole organs [76]. CYN induced changes in CMT 
orientation were not caused by the inhibition of ( $\alpha$ - or $\beta$-) tubulin synthesis: Western blots revealed that CYN increases and not decreases the amount of $\beta$-tubulin, which does not correspond with its protein synthesis inhibitory effects ([28]; see also sections 2 and 4 of this review). It is worth mentioning, that similar increases in the levels of $\beta$-tubulin were observed in CYN treated Caco-2 cells [56], but not in freshwater mussels [55]. Early studies indicate that high tubulin levels alter the number of MTs as a consequence of MTOC dysfunctioning in dividing cells, leading to abnormal mitotic MT assembly [79].

(vi) CYN increases the abundance of a protein participating in the assembly of the plastid division ring complex in lettuce [59], although the consequences of this change in plastid fission are not known.

What are the molecular mechanisms laying behind the effects of CYN on eukaryotic cell cycle? CYN is considered as a protein synthesis inhibitor, hence its effects are apparently related to the decrease in the levels of cell cycle regulators. However, the biochemical targets of the cyanotoxin seem to be more complex: (i) CYN increases expression (transcription) of the CDKI CDKN1A through p53 [70] which can be a cause of cell cycle arrest. This is true even though no changes in the transcript level of p53 were detected in CYN treated cells [61]. However, posttranscriptional p53 activation and subsequent activation of p53 dependent gene transcriptional events can be activated via DNA damage by CYN in other organisms/cell types, (see Section 3.3 of this review). (ii) the levels of several proteins including those having crucial roles in the regulation of mitosis increase and not decrease in the presence of CYN (it is true though, that such increases are characteristic only for part of the organisms/tissues studied). This includes $\beta$ tubulin and actin isoforms both in animal and plant organisms and may contribute to cyanotoxin induced abnormal mitosis $[28,55,56]$. (iii) CYN may have important consequences on cell cycle, since it is an inhibitor of pyrimidine nucleotide biosynthesis (see section 2.2. of this review). Such inhibitors (e.g. methotrexate) are known to block cells in the $\mathrm{S}$ phase and cause subsequent apoptosis e.g. in primary $\mathrm{T}$ lymphocytes [80]. Moreover, depletion of cytidine and uridine will lead to a p53-dependent arrest of several human cell lines at G0/G1 [81]. As stated above, CYN is able of delaying the onset of mitosis [49], however the cell cycle phase involved is not known. In the light of these findings, one very important future research topic is revealing whether the cyanotoxin affects $\mathrm{G} 0 / \mathrm{G} 1, \mathrm{G} 1 / \mathrm{S}$ or $\mathrm{G} 2 / \mathrm{M}$ transition. The possible medical implication is for example the potential use of CYN as a cell cycle blocker/inhibitor in the treatment of malignant tumors.

\subsection{Effects on the endomembrane system and mitochondria}

Relevant effects of CYN were revealed mainly by TEM studies and most alterations can be related to cyanotoxin induced cell death (see section 3.3. of this review). The first and one of the most complex studies on this issue was performed by Terao et al. [40] with mice i.p. injected with CYN. Ultrastructural changes of hepatic cells occurred by three consequent stages: (1.) detachment of ribosomes from RER, a phenomenon that occurred in the presence of CHM, a well-known eukaryotic protein synthesis inhibitor, too. This occurred concomitantly with the reduction of nucleolus size and its condensation. This shows that the increased free ribosome population originates from RER alterations and not from increased ribosome biogenesis. It is interesting that CYN and CHM have similar effects in mouse liver. The primary effect of the latter drug was initially thought to be the inhibition of the transfer of aminoacil-tRNA to the nascent peptide on ribosomes [82]. Later it turned out that CHM inhibits the large ribosomal subunit translocation step during translation [83]. (2.) The formation of multiple membrane-layer vesicles and increase in the abundance of SER membranes. Abundant SER system did not originate from detachment of ribosomes from RER, because cycloheximide did not induce this second stage. This observation suggested that other mechanisms than protein synthesis inhibition may contribute to CYN toxicity. (3.) the formation of abundant lipid droplets, autophagosomes and cell death. These alterations are probably related to the changes presented above (2.). The possible mechanism of premature ribosome detachment from RER could be degradation or dysfunction of putative "ribosomal protein receptors" localized at the surface of ER [84]. Later on it turned out that the ER contains indeed a complex responsible for ribosome targeting to the ER and channeling nascent proteins to the lumen or RER. For example, the SRP/SRSec61 proteins play an essential role in attachment of ribosomes and folding/correct localization of ER transmembrane proteins [85]. It is worth mentioning that the reticulocyte lysate used by Terao et al. [40] for the translation assay involving CYN treatments could contain fragments of ER membranes, thus CYN could influence ribosome attachment to these membrane fragments. Moreover, CYN decreased protein content of microsomes known to be composed of ER membrane fractions. It is worth mentioning that Froscio et al. [47] suggested that indeed, CYN does not inhibit protein synthesis directly at the ribosome level.

Gutiérrez-Praena et al. [86] performed studies in human intestinal (Caco-2) cells and showed alterations in the organization of Golgi apparatus and mitochondria. These changes, together with the increase in the formation of lipid droplets and multivesicular bodies (MVB) indicated that the cyanotoxin induced elevated ROS formation that led to cell death. Intense vacuolization and abundant lysosome formation were also detected in brain neuronal cells of tilapia fish exposed to subchronical doses of CYN [87].

Hepatic cells and cardiac muscle cells of CYN treated tilapia fish showed abundant mitochondria that were often swollen at $1 \mathrm{~d}$ of cyanotoxin exposure (i.p. or orally applied $0.2 \mathrm{mg} \mathrm{kg}^{-1} \mathrm{CYN}$ ) and loss of mitochondria at long- 
term exposures. Hepatic and kidney cells long-term exposed to the cyanotoxin showed frequently increased nuclear diameter [88]. Mitochondrial swelling can be an indicator of oxidative stress (see [89] for an example). It may be followed by membrane rupture, cytochrome c release, consequently disruption of the inner mitochondrial membrane electron transport chain and caspase-3 activation, events related to PCD [90].

\subsection{Effects on cell viability, DNA integrity and the induction of cell death}

Most of papers dealing with the cellular effects of CYN in eukaryotes are reporting alterations of viability, induction of oxidative stress and alterations of chromatin/DNA integrity. Various types of cell death- programmed cell death (PCD)/apoptosis and necrosis were detected. The first event that indicated possible CYN induced cell death was liver necrosis induced by Cylindrospermopsis raciborskii extracts in mice. The authors suspected this cyanobacterial strain was responsible for the incidence of human hepatoenteritis in Palm Island, Australia [91]. Early studies include those of Humpage et al. [75] and Shen et al. [92]. The former study showed CYN induced formation of micronuclei in human cells (WIL2-NS lymphoblastoid cells). Both centromerepositive and -negative micronuclei were detected, indicating that both chromatid mis-segregation and DNA strand breaks occurred. The latter study showed CYN induced DNA degradation (detected by alkaline gel electrophoresis of DNA extracted from Balb/c mouse liver), pointing out that triggering of cell death can be the main event in CYN induced cytotoxicity.

Different cell viability assay methods show that the effects of CYN are largely dependent on the cell type studied. For example, there were significant decreases in the viability of CYN treated murine hepatocytes or human granulosa cells, but no such changes could be detected in rat hepatocytes or HeLa cells [35, 37, 93-95]. Inhibitors of CYP450 activity prevented mouse hepatocytes from the CYN induced loss of viability [37].

Current evidence suggests that CYN induced cell death is mediated through reactive oxygen species (ROS) generation. This will induces DNA damage including single- or double strand breaks that will arrest cell cycle (see section 3.1. of this review) and initiate PCD/apoptosis. There are numerous subcellular changes at the cell cycle regulation and endomembrane/ mitochondrial level indicating that CYN induces cell death (see sections 3.1. and 3.2. of this review). In the present section we will analyze CYN induced ROS generation and changes occurring in nucleus underlining the possible mechanisms leading to these changes- to check the validity of the sequence of events proposed above. CYN induced tissue necrosis and its relationship to PCD/apoptosis are also discussed.

The first indication of possible CYN induced oxidative stress came from the work of Runnegar et al. [21, 63, 64]. They showed decreased viability of CYN treated cultured rat hepatocytes (based on the LDH release assay), accompanied by decreased glutathione (GSH) levels probably due to the inhibition of its biosynthesis. CYP450 inhibitors partially prevented this effect, showing that this monooxygenase system plays a role in CYN toxicity. Gutiérrez-Praena et al. [96] have treated tilapia fish orally and i.p. with $200 \mu \mathrm{g} \mathrm{kg}^{-1}$ CYN for 1 and 5d and observed increases of glutathione-Stransferase (GST) transcript and protein levels as well as its activity. In contrast, glutathione peroxidase (GPx) transcript level increased, but its activity did not change significantly. However, studies performed with the human cell lines HUVEC and Caco-2 as well as rat and fish cell cultures showed increases, rather than decreases of glutathione synthesis or GSH levels, indicating this parameter is largely dependent on the cell line studied. Meanwhile, ROS elevation (mainly $\mathrm{H}_{2} \mathrm{O}_{2}$ ) induced by $\mathrm{CYN}$ was detected in these cell lines [50, 53, 56, 86, 88]. Concomitant reactive oxygen/nitrogen species (RONS) elevation and no changes in GSH/GSSG ratio or GST activities were detected in hepatocytes of the fish Prochilodus lineatus [97, 98]. One of the most comprehensive studies on the relationship between CYN induced oxidative stress and cell death was performed by Štraser et al. [62]. They added 2', 7'-dichlorofluorescein diacetate (DCFH-DA) to HepG2 cells. DCFH-DA is a known marker of intracellular ROS, especially $\mathrm{H}_{2} \mathrm{O}_{2}$. Subsequent adding of CYN to cells increased the intensity of DCFH-DA fluorescence, indicating that the cyanotoxin could increase ROS formation. At lower non-cytotoxic CYN concentrations $\left(0.25\right.$ and $\left.0.5 \mu \mathrm{g} \mathrm{mL}^{-1}\right), \mathrm{CYN}$ induced DNA damage as revealed by the Comet assay. Strand break, but no oxidative DNA damage could be detected. Thus, DNA strand breaks were not induced by ROS elevation. At these CYN concentrations, there was no induction of apoptosis markers as revealed by like Caspase 3/7 activities or Annexin V labeling. All these results show that CYN does not induce typical apoptosis in HepG2 cells at sub-cytotoxic concentrations for up to $24 \mathrm{~h}$ exposure. The higher transcription level of $\mathrm{Bcl} 2$, than $\mathrm{Bax}$ in human peripheral blood lymphocytes treated for $24 \mathrm{~h}$ with $0.5 \mu \mathrm{g} \mathrm{mL} \mathrm{mL}^{-1}$, CYN shows another cell type where CYN does not induce typical apoptosis [99]. The authors have shown the formation of micronuclei, nucleoplasmic bridges and nuclear buds/blebbing indicating fragmentation of nuclei, DNA misrepair and abnormal S-phase DNA amplification. Meanwhile there were only partial increases at the mRNA level of enzymes related to oxidative stress defence. Transcript levels of p53 and genes up-regulated by this transcription factor (MDM2 and GADD45 $\alpha$ ) as well as of CYP450 related mRNAs (suggesting that CYN toxicity is mediated here by cCYP450 as in several other experimental systems) increased as well. However, changes at the transcript level do not necessarily mean that the corresponding protein levels are also increasing, since post-transcriptional regulatory mechanisms may alter protein expression. This was postulated in the above work as well [99]. For tilapia fish, CYN induced oxidative stress (glutathione imbalance, increase of NADPH oxidase activity) without oxidative DNA damage was also observed [65]. All these data suggest that in several human cell types (and in tilapia fish) CYN induces atypical PCD. In contrast, Gácsi et al. [72] detected typical apoptosis in $\mathrm{CHO}-\mathrm{K} 1$ cells. It is true, that higher 
CYN concentrations $\geq 1 \mu \mathrm{M}$ (corresponding to $\geq 2.4 \mu \mathrm{g} \mathrm{mL}$ 1) were used, than in the Žegura et al. [99] study. Interestingly, these apoptotic cells gradually turned into necrosis, although the mechanism of this phenomenon remains to be elucidated. In the same cell line, Lankoff et al. [73] detected typical apoptosis at lower CYN concentrations (0.1-2 $\mu \mathrm{g} \mathrm{mL}^{-1}$ ) and shorter exposure times (3-21 h vs. 12-48 $\mathrm{h}$ used in the former study) that might explain the lower percentage of apoptotic cells. This slighter apoptosis induction was characteristic even at metabolic activation by CYP450 known to be related to CYN toxicity. However, necrosis was still detected in their system-moreover, in higher percentage than apoptotic cells- which somehow contradicts the findings of Gácsi et al. [72] and makes the apoptosis-necrosis transition hypothesis to be questionable. In addition, Fessard and Bernard [100] showed slight apoptotic effect of CYN in CHO-K1 cells at concentrations/exposure times comparable to the above two studies, but they did not detect DNA strand breaks by the Comet assay. The slight differences reported by different research groups for CYN treated $\mathrm{CHO}-\mathrm{K} 1$ cells might be attributed to the different experimental conditions employed. The presence of pyknotic nuclei and detection of DNA strand breaks suggested the onset of apoptosis in mice i.p. or orally treated with CYN as well [101].

CYN as well as its metabolite, deoxycylindrospermopsin induced glutathione imbalance and caused altered superoxide dismutase (SOD) and catalase (CAT) activities in liver and kidney of tilapia fish and in human lymphocytes [102, 103]. For SOD and CAT, activity changes were dependent on CYN dose, exposure and the organ affected. SOD activity increased in both organs at $7 \mathrm{~d}$ exposure, while for kidney it decreased at longer toxin treatment. For CAT, liver activity increased at $7 \mathrm{~d}$ and decreased at longer exposure, while for kidney, it decreased at both exposures. These biochemical changes show that CYN induced oxidative stress and the cell redox state/ defence mechanisms against ROS were altered over time. Meanwhile, oxidative DNA damage was detected: changes at the DNA level were observed during CYN induced oxidative stress. It should be noted that environmentally relevant cyanotoxin doses (10 and $100 \mu \mathrm{g}$ $\mathrm{L}^{-1}$ ) were used in this study, raising the possibility that even human health could be affected by CYN via the food chain. It should be noted, that CYN concentrations in the $\mu \mathrm{g} \mathrm{L} \mathrm{L}^{-1}$ range are generally accepted to occur during excessive proliferation of cyanobacteria that are producing it [102; 104]. Later on, it turned out the same research team showed that intense lipid peroxidation occurred concomitantly with endomembrane changes and chromatin condensation in different cell types of tilapia (including neurons) showing once again the relationship between CYN induced ROS elevation and apoptosis in this organism ([87] and see section 3.2. of this review).

In relation to $\mathrm{CYN}$ induced oxidative stress, protein carbonyl content, as a biomarker of protein oxidation, was assayed by Gutiérrez-Praena et al. [65]. In liver and kidneys of CYN treated tilapia fish, elevated amounts (nmol) of carbonyl $\mathrm{mg}^{-1}$ protein were detected. In kidneys protein oxidation was more pronounced than in liver.
Tissue damage/necrosis was reported for several mammalian organs/tissues, most of the studies being carried out in hepatic tissues (see [37] for a summary and [105]).

In general, all the above studies show that the proapoptotic effects of CYN in vertebrate cells are largely celltype specific. Many mammalian cell types are affected by the cyanotoxin, which points out the potential human health hazard of CYN exposure.

For higher plants, there is little knowledge on cell death inducing effects of CYN. Exposure of both monocot and dicot models (Phragmites australis and Vicia faba) to this cyanotoxin show leads to cell death symptoms, when exposed to this cyanotoxin. These include nuclear blebbing and fragmentation (showing possible PCD processes) and root necrosis [28, 49]. However a third model, Sinapis alba does not show necrotic symptoms at all [68]. Loss of chlorophyll indicating senescence was reported for $S$. alba, Oryza sativa as model crops and Hydrilla verticillata, an aquatic macrophyte [67, 106, 107]. At the biochemical level, increases in the levels of $\mathrm{H}_{2} \mathrm{O}_{2}$ and/or activities of ROS scavenging enzymes (CAT, peroxidase/POD, GPx) were reported in S. alba, O. sativa and Lemna minor [67, 107, 108], indicating that CYN treatments led to oxidative stress. Interestingly, most of ROS scavenging enzymes with increased expression induced by CYN in lettuce were proteins localized in chloroplasts. Meanwhile, the levels of several molecular chaperones localized in chloroplasts decreased, but HSP70 and HSP90 increased. This was observed for a putative $\mathrm{Zn}$-dependent protease as well [59]. Research on CYN treated lettuce indicated that PCD-like processes were initiated in chloroplasts. It is known, that The synthesis of pyrimidine nucleotides is localized in plastids in case of plants [109]. As we stated before, CYN inhibits pyrimidine nucleotide synthesis and may induce PCD via this mechanism. Elevations of oxidative stress defence enzyme activities show that plants can counteract toxic effects of CYN to some extent.

Both crude extracts of CYN producing Aphanizomenon ovalisporum and purified CYN induced increases of protease activities of Lemna minor and Wolffia arrhiza [54], however the nature of these proteases and their direct involvement in plant PCD remains to be established. In spite of all these data on vascular plants, the understanding of the mechanism of CYN induced cell death or whether PCD-related symptoms and necrosis are interrelated processes- especially the relationship between oxidative stress and nuclear/DNA alterations- still remain to be established for plants. Since Cell death related responses were detected in aquatic macrophytes that can be in contact with CYN under natural conditions. The ecological impact- and entrance into food chain at the level of primary producers- of CYN exposure is possible. 
Table 1 Cellular changes induced by CYN in human, animal and plant cells. CYN (MW $=416)$ concentration units are given according to the authors of works referred. Concentrations refer to purified cyanotoxin, except when specified.

\begin{tabular}{|c|c|c|c|c|}
\hline Alteration induced & $\begin{array}{l}\text { Target } \\
\text { organism/cell } \\
\text { type, } \\
\text { experimental } \\
\text { system }\end{array}$ & $\begin{array}{l}\text { CYN } \\
\text { concentration and } \\
\text { exposure time (if } \\
\text { available) }\end{array}$ & $\begin{array}{l}\text { Molecular/ biochemical } \\
\text { mechanism }\end{array}$ & References \\
\hline \multicolumn{5}{|c|}{ Cell cycle, related cytoskeleton and chromatin changes } \\
\hline $\begin{array}{l}\text { inhibition of mitosis; } \\
\text { slight/ not significant } \\
\text { cell cycle arrest at } \\
\text { G0/G1 and increase in } \\
\text { the length of S phase }\end{array}$ & $\begin{array}{l}\text { human T- } \\
\text { lymphocytes }\end{array}$ & $\begin{array}{l}1 \mu \mathrm{g} \mathrm{mL} L^{-1} \text {, up to } 48 \\
\text { h exposure }\end{array}$ & not investigated & [69] \\
\hline $\begin{array}{l}\text { decrease of mitotic } \\
\text { index, blocking cells in } \\
\text { early mitosis, } \\
\text { destabilization of MFs, } \\
\text { decrease of density and } \\
\text { rearrangement of MTs }\end{array}$ & CHO-K1 cells & $\begin{array}{l}0.1-2 \mu \mathrm{g} \mathrm{mL}^{-1}, 3-24 \\
\mathrm{~h} ; 2 \mu \mathrm{M}(0.83 \mu \mathrm{g} \\
\left.\mathrm{mL}^{-1}\right), 24 \mathrm{~h}\end{array}$ & $\begin{array}{l}\text { presumably, protein } \\
\text { synthesis inhibition }\end{array}$ & {$[72,73,100]$,} \\
\hline $\begin{array}{l}\text { decrease of cell division } \\
\text { activity and inhibition of } \\
\text { differentiation }\end{array}$ & $\begin{array}{l}\text { undifferentiated } \\
\text { murine } \\
\text { embryonic stem } \\
\text { cells } \\
\end{array}$ & $1 \mathrm{ng} \mathrm{mL} L^{-1}, 168 \mathrm{~h}$ & $\begin{array}{l}\text { presumably, protein } \\
\text { synthesis inhibition }\end{array}$ & [74] \\
\hline $\begin{array}{l}\text { decrease of non-mitotic } \\
\text { MT density, } \\
\text { rearrangement of MTs } \\
\text { and/or increase of } \beta \text { - } \\
\text { tubulin level }\end{array}$ & $\begin{array}{l}\text { Phragmites } \\
\text { australis root } \\
\text { tip cells, Caco-2 } \\
\text { cells }\end{array}$ & $\begin{array}{l}0.5-10 \mu \mathrm{g} \mathrm{mL}^{-1}, 10 \\
\mathrm{~d} ; 1,5 \mu \mathrm{M}(0.41,2 \\
\mu \mathrm{g} \mathrm{mL}-1), 4-48 \mathrm{~h}\end{array}$ & $\begin{array}{l}\text { the mechanism of tubulin } \\
\text { increase is not known, but } \\
\text { these two phenomena are } \\
\text { interrelated }\end{array}$ & {$[28,56,72]$,} \\
\hline $\begin{array}{l}\text { transient stimulation of } \\
\text { mitosis }\end{array}$ & $\begin{array}{l}\text { P. australis, } \\
\text { Vicia faba root } \\
\text { tip cells }\end{array}$ & $\begin{array}{l}0.1-5 \mu \mathrm{g} \mathrm{mL}^{-1}, \\
\text { long-term } \\
\text { exposures (10 and } 6 \\
\mathrm{~d}, \text { respectively) } \\
\end{array}$ & not known & {$[28,49]$} \\
\hline $\begin{array}{l}\text { dramatic inhibition of } \\
\text { mitosis (to near zero } \\
\text { mitotic activity) }\end{array}$ & $\begin{array}{l}V . \text { faba root tip } \\
\text { cells }\end{array}$ & $\begin{array}{l}2.5-20 \mu \mathrm{g} \mathrm{mL}^{-1}, 6 \mathrm{~d} \\
\text { exposure }\end{array}$ & not known & [49] \\
\hline $\begin{array}{l}\text { delay of the onset of } \\
\text { mitosis in S-phase } \\
\text { synchronized cells }\end{array}$ & $\begin{array}{l}V . \text { faba root tip } \\
\text { cells }\end{array}$ & $5 \mu \mathrm{g} \mathrm{mL}^{-1}$ & $\begin{array}{l}\text { delay of de novo protein } \\
\text { synthesis }\end{array}$ & [49] \\
\hline $\begin{array}{l}\text { abnormal mitotic MT } \\
\text { organization, sporadic } \\
\text { appearance of lagging } \\
\text { chromosomes }\end{array}$ & $\begin{array}{l}\text { P. australis, } V \text {. } \\
\text { faba root tip } \\
\text { cells }\end{array}$ & $\begin{array}{l}0.1-20 \mu \mathrm{g} \mathrm{mL}^{-1} \text {, } \\
\text { relatively long-term } \\
\text { exposures ( } 10 \text { and } \\
3,6 \mathrm{~d} \text {, respectively) }\end{array}$ & $\begin{array}{l}\text { probably the decrease in } \\
\text { the number of MTOCs } \\
\text { caused by excess tubulin } \\
\text { production and inhibition } \\
\text { of the synthesis of } \\
\text { proteins involved in } \\
\text { normal PPB formation }\end{array}$ & {$[28,49]$} \\
\hline $\begin{array}{l}\text { up-regulation of genes } \\
\text { involved in cell cycle } \\
\text { arrest }\end{array}$ & HepG2 cells & $\begin{array}{l}0.5 \mu \mathrm{g} \mathrm{mL}^{-1}, 12,24 \\
\mathrm{~h}\end{array}$ & not known & [61] \\
\hline \multicolumn{5}{|c|}{ Endomembrane system } \\
\hline $\begin{array}{l}\text { detachment of } \\
\text { ribosomes from RER, } \\
\text { the increase in the } \\
\text { abundance of SER, the } \\
\text { formation of } \\
\text { multimembrane }\end{array}$ & male ICR mice & $\begin{array}{l}\text { i.p. injection with } \\
0.2 \mathrm{mg} \mathrm{kg}^{-1} \mathrm{CYN} \text {, } \\
16-100 \mathrm{~h}\end{array}$ & $\begin{array}{l}\text { inhibition of protein } \\
\text { synthesis, other } \\
\text { (unknown) mechanisms }\end{array}$ & [40] \\
\hline
\end{tabular}




\begin{tabular}{|c|c|c|c|c|}
\hline $\begin{array}{l}\text { structures and } \\
\text { autophagosomes and } \\
\text { finally, cell death }\end{array}$ & & & & \\
\hline $\begin{array}{l}\text { mitochondrial and Golgi } \\
\text { disorganization, } \\
\text { accumulation of lipid } \\
\text { droplets, segregation of } \\
\text { nucleoli, formation of } \\
\text { lamellipodia (the latter, } \\
\text { only for HUVEC cells), } \\
\text { formation pf MVBs, } \\
\text { apoptosis }\end{array}$ & $\begin{array}{l}\text { Caco- } 2 \text { cells, } \\
\text { HUVEC cells }\end{array}$ & $\begin{array}{l}0.375-2.5 \mu \mathrm{g} \mathrm{mL}^{-1}, \\
24,48 \mathrm{~h}\end{array}$ & induction of ROS & {$[50,86]$} \\
\hline $\begin{array}{l}\text { intense vacuolization, } \\
\text { lysosome formation, } \\
\text { mitochondrial swelling, } \\
\text { chromatin condensation }\end{array}$ & $\begin{array}{l}\text { tilapia, } \\
\text { neuronal, } \\
\text { hepatic and } \\
\text { kidney cells }\end{array}$ & $\begin{array}{l}\text { Aphanizomenon } \\
\text { ovalisporum lysate } \\
\text { containing } 10 \mu \mathrm{g} \mathrm{L}- \\
{ }^{1} \mathrm{CYN}, 14 \mathrm{~d} \text { for } \\
\text { neuronal cells; } \\
\text { injection or oral } \\
\text { administration with } \\
0.2 \mathrm{mg} \mathrm{kg}^{-1} \mathrm{CYN} \text {, } \\
24 \text { h for hepatic and } \\
\text { kidney cells }\end{array}$ & $\begin{array}{l}\text { probably oxidative stress- } \\
\text { induced initiation of cell } \\
\text { death }\end{array}$ & {$[87,88]$} \\
\hline & & Cell death & & \\
\hline chromosome breakage & $V$. faba root tips & $0.1-5 \mu \mathrm{g} \mathrm{mL}^{-1}, 3 \mathrm{~d}$ & $\begin{array}{l}\text { dsDNA breaks occurring } \\
\text { during CYN induced PCD }\end{array}$ & [49] \\
\hline $\begin{array}{l}\text { micronucleus induction, } \\
\text { whole chromosome loss, } \\
\text { no chromosomal break }\end{array}$ & $\begin{array}{l}\text { WIL2-NS } \\
\text { lymphoblastoid } \\
\text { cell line }\end{array}$ & $1-10 \mu \mathrm{g} \mathrm{mL}^{-1}, 24 \mathrm{~h}$ & $\begin{array}{l}\text { probably loss of spindle } \\
\text { MT-kinetochore } \\
\text { connection }\end{array}$ & {$[75]$} \\
\hline $\begin{array}{l}\text { typical apoptosis } \\
\text { detected by Annexin-V } \\
\text { labeling and cell } \\
\text { rounding/blebbing at } \\
\text { low CYN concentration/ } \\
\text { short exposure time and } \\
\text { necrosis at all CYN } \\
\text { concentrations and } \\
\text { exposure times }\end{array}$ & CHO-K1 cells & $\begin{array}{l}0.1-2 \mu \mathrm{g} \mathrm{mL} \mathrm{m}^{-1}, 3- \\
21 \mathrm{~h} ; 1-50 \mu \mathrm{M} \\
(0.41-20.8 \mu \mathrm{g} \mathrm{mL}- \\
\left.{ }^{1}\right), 12-48 \mathrm{~h} \\
\text { exposure }\end{array}$ & $\begin{array}{l}\text { presumably, inhibition of } \\
\text { protein synthesis; } \\
\text { cytoskeletal } \\
\text { reorganization is likely to } \\
\text { be involved }\end{array}$ & {$[72,73,100]$} \\
\hline $\begin{array}{l}\text { nuclear shrinking/ } \\
\text { chromatin condensation, } \\
\text { nuclear blebbing, } \\
\text { possible apoptosis }\end{array}$ & $\begin{array}{l}\text { Male Swiss } \\
\text { albino mice- } \\
\text { liver, kidney, } \\
\text { tilapia- neuronal } \\
\text { cells }\end{array}$ & $\begin{array}{l}\text { i.p. and oral } \\
\text { treatment, } 100-200 \\
\mu \mathrm{g} \mathrm{kg}^{-1} \text { (i.p.) and 2, } \\
4 \mathrm{mg} \mathrm{kg}^{-1} \text { (gavage), } \\
24 \mathrm{~h}_{\text {for mice; } 10} \\
\mu \mathrm{g} \mathrm{L}^{-1}, 14 \mathrm{~d} \text { for } \\
\text { tilapia }\end{array}$ & not known & {$[87,101]$} \\
\hline $\begin{array}{l}\text { atypical apoptosis or } \\
\text { non-apoptotic PCD, the } \\
\text { formation of } \\
\text { micronuclei, nuclear } \\
\text { blebbing, nucleoplasmic } \\
\text { bridges }\end{array}$ & $\begin{array}{l}\text { human } \\
\text { peripheral blood } \\
\text { lymphocytes } \\
\text { (HPBL), } \\
\text { HepaRG, Caco- } \\
2 \text { cells }\end{array}$ & $\begin{array}{l}0.05,0.5 \mu \mathrm{g} \mathrm{mL}-1 \\
4,21 \mathrm{~h} \text { for } \mathrm{HPBL} ; \\
0.04-2 \mu \mathrm{g} \mathrm{mL}^{-1}, 24 \\
\mathrm{~h} \text { for HepaRG and } \\
\text { Caco- } 2 \text { cells }\end{array}$ & $\begin{array}{l}\text { abnormal DNA } \\
\text { amplification, DNA mis- } \\
\text { repair during S phase; } \\
\text { elevation of ROS; } \\
\text { elevation at the transcript } \\
\text { level of GCLC, GPx and } \\
\text { SOD (but not CAT); p53 } \\
\text { and related transcripts; }\end{array}$ & {$[88,99,110]$} \\
\hline $\begin{array}{l}\text { chromatin and nucleolar } \\
\text { disorganization, } \\
\text { chromatin fragmentation }\end{array}$ & $\begin{array}{l}\text { Caco- } 2 \text { cells } V \text {. } \\
\text { faba lateral root } \\
\text { tip cells }\end{array}$ & $\begin{array}{l}0.625,2.5 \mu \mathrm{g} \mathrm{mL}^{-1} \\
24,48 \mathrm{~h} \text { for Caco-2 } \\
\text { cells; } 10-20 \mu \mathrm{g} \mathrm{mL}- \\
1,6 \mathrm{~d} \text { for } V . \text { faba }\end{array}$ & $\begin{array}{l}\text { probably induction of } \\
\text { ROS and DNA strand } \\
\text { breaks }\end{array}$ & {$[49,86]$} \\
\hline cell death? & tilapia, liver, & immersion in & oxidative DNA damage at & {$[102]$} \\
\hline
\end{tabular}




\begin{tabular}{|c|c|c|c|c|}
\hline & kidney & $\begin{array}{l}\text { Aphanizomenon } \\
\text { ovalisporum cells } \\
\text { to obtain } 10 \text { and } \\
100 \mu \mathrm{g} \mathrm{mL} \mathrm{C}^{-1} \mathrm{CYN} \\
\text { and } 0.46,4.6 \mu \mathrm{g} \\
\mathrm{mL}^{-1} \text { deoxy-CYN, } \\
7,14 \mathrm{~d}\end{array}$ & $\begin{array}{l}\text { higher CYN doses; } \\
\text { oxidative stress, increase } \\
\text { of lipid peroxidation at } 14 \\
\text { d of exposure, increased } \\
\text { GST activity in liver/ } \\
\text { decrease in kidney, } \\
\text { increase of GPx activity } \\
\text { (in kidney), decrease of } \\
\text { GSH/GSSG ratio, increase } \\
\text { of GCS activity (in } \\
\text { kidney), changes of CAT, } \\
\text { SOD activities and } \\
\text { increase of protein } \\
\text { oxidation at higher } \\
\text { dose/14d exposure }\end{array}$ & \\
\hline $\begin{array}{l}\text { irregular nucleus shape, } \\
\text { necrosis }\end{array}$ & tilapia, intestine & $\begin{array}{l}200,400 \mu \mathrm{g} \mathrm{kg}^{-1} \\
\text { gavage, } 24 \mathrm{~h}\end{array}$ & $\begin{array}{l}\text { oxidative stress has less } \\
\text { effects, but generally not } \\
\text { known }\end{array}$ & [111] \\
\hline $\begin{array}{l}\text { disorganization of } \\
\text { cardiac myofibrils and } \\
\text { intestinal microvilli, } \\
\text { necrosis of enterocytes }\end{array}$ & tilapia & $\begin{array}{l}\text { pretreatment with } \\
\mathrm{N} \text {-acetylcysteine }+ \\
\text { single dose of } 200 \\
\mu \mathrm{g} \mathrm{kg}{ }^{-1} \mathrm{CYN}, 24 \mathrm{~h} \\
\text { (use of purified } \\
\mathrm{CYN} \text { and } \\
\text { cyanotoxin } \\
\text { containing A. } \\
\text { ovalisporum lysate) }\end{array}$ & not investigated & {$[31]$} \\
\hline necrosis & $\begin{array}{l}\text { liver of male } \\
\text { Swiss Albino or } \\
\text { ICR mice, liver, } \\
\text { kidney and } \\
\text { pancreas of } \\
\text { tilapia fish, root } \\
\text { tissues of } P \text {. } \\
\text { australis and } V . \\
\text { faba }\end{array}$ & $\begin{array}{l}\text { i.p. administration } \\
\text { of liophilized cells } \\
\text { of } \\
\text { Cylindrospermopsis } \\
\text { raciborskii to male } \\
\text { Swiss Albino mice, } \\
70 \mathrm{mg} \mathrm{kg}^{-1}, 24 \mathrm{~h} \text {; } \\
\text { purified CYN- for } \\
\text { mice and tilapia: } \\
\text { i.p. injection or oral } \\
\text { administration } \\
\text { (tilapia) with } 0.2 \\
\text { mg kg }{ }^{-1} \mathrm{CYN}, 48 \mathrm{~h} \\
\text { for mice, or } 1,5 \mathrm{~d} \\
\text { for tilapia; for } \\
\text { plants: } 0.1-40 \mu \mathrm{g} \\
\text { mL }{ }^{-1}, 10 \mathrm{~d} \text { for } P . a . \\
\text { and } 6 \mathrm{~d} \text { for } V . f .\end{array}$ & not investigated & $\begin{array}{l}{[9,28,49,88,} \\
105]\end{array}$ \\
\hline apoptosis and necrosis & $\begin{array}{l}\text { pregnant CD-1 } \\
\text { mice, liver }\end{array}$ & $50 \mu \mathrm{g} \mathrm{kg}^{-1} \mathrm{day}^{-1}, 5 \mathrm{~d}$ & $\begin{array}{l}\text { controversial (not only } \\
\text { protein synthesis } \\
\text { inhibition is responsible) }\end{array}$ & {$[60]$} \\
\hline $\begin{array}{l}\text { cell death of unspecified } \\
\text { type }\end{array}$ & $\begin{array}{l}\text { cultured Swiss } \\
\text { albino mice, rat } \\
\text { hepatocytes, } \\
\text { tilapia fish- } \\
\text { liver, kidney }\end{array}$ & $\begin{array}{l}0.5-5 \mu \mathrm{M}(0.2-2 \mu \mathrm{g} \\
\left.\mathrm{mL}^{-1}\right), 17 \mathrm{~h} \text { for } \\
\text { mammals; } 200 \mu \mathrm{g} \\
\mathrm{kg}^{-1}, \text { i.p. or gavage, } \\
24 \mathrm{~h} \text { for fish }\end{array}$ & $\begin{array}{l}\text { glutathione (GSH) } \\
\text { depletion, but oxidative } \\
\text { stress induced DNA } \\
\text { damage might not be } \\
\text { involved; for tilapia- } \\
\text { decrease of GCS and } \\
\text { increase of NADPH } \\
\text { oxidase activity and lipid } \\
\text { peroxidation }\end{array}$ & $\begin{array}{l}{[21,37,64,} \\
65]\end{array}$ \\
\hline
\end{tabular}




\begin{tabular}{|c|c|c|c|c|}
\hline cell death? & $\begin{array}{l}\text { Oryza sativa, } \\
\text { Sinapis alba, } \\
\text { Lactuca sativa, } \\
\text { Lemna minor } \\
\text { plants/seedlings, } \\
\text { lungs of mice } \\
\text { intratracheally } \\
\text { injected }\end{array}$ & $\begin{array}{l}\text { CYN containing } \\
\text { crude } \\
\text { Aphanizomenon } \\
\text { ovalisporum } \\
\text { extracts; } 0.05 \mu \mathrm{g} \\
\mathrm{mL}^{-1} \text { purified CYN } \\
\text { for mustard and } 1- \\
100 \mu \mathrm{g} \mathrm{L}^{-1} \text { purified } \\
\mathrm{CYN} \text { for lettuce; } \\
2.5 \text { and } 25 \mu \mathrm{g} \mathrm{L}^{-1} \\
\text { purified CYN for } \\
\text { duckweed, } 48 \mathrm{~h} \text { for } \\
\text { rice, } 4 \mathrm{~d} \text { for } \\
\text { mustard, 5-10d for } \\
\text { lettuce, } 1-7 \mathrm{~d} \text { for } \\
\text { duckweed grown } \\
\text { photoperiodically; } \\
\text { mouse treatments, } \\
70 \mu \mathrm{g} \text { kg }{ }^{-1}, 2-96 \mathrm{~h}\end{array}$ & $\begin{array}{l}\text { oxidative stress induction } \\
\text { in higher plants and } \\
\text { mammals; probable } \\
\text { induction of oxidative } \\
\text { stress signalling and PCD, } \\
\text { increase of GST and/or } \\
\text { GPx, POD, } \mathrm{SOD} \text {, GR } \\
\text { activities, } \mathrm{H}_{2} \mathrm{O}_{2} \text { levels }\end{array}$ & $\begin{array}{l}{[67,107,108,} \\
112,113]\end{array}$ \\
\hline loss of cell viability & $\begin{array}{l}\text { fish liver cell } \\
\text { line PLHC-1 }\end{array}$ & $\begin{array}{l}2-8 \mu \mathrm{g} \mathrm{mL}^{-1}, 24-48 \\
\mathrm{~h}\end{array}$ & $\begin{array}{l}\text { oxidative stress: increase } \\
\text { of ROS, decrease of } \\
\text { tetrazolium salt reduction, } \\
\text { transient increase of GSH } \\
\text { content and GCS activity }\end{array}$ & {$[53]$} \\
\hline $\begin{array}{l}\text { cell death, but no } \\
\text { apoptosis }\end{array}$ & HepG2 cells & $\begin{array}{l}0.25,0.5 \mu \mathrm{g} \mathrm{mL}^{-1}, \\
12,24 \mathrm{~h}\end{array}$ & $\begin{array}{l}\text { elevation of ROS, non- } \\
\text { oxidative DNA damage } \\
\text { (strand breaks) but no } \\
\text { induction of Caspase } 3 / 7 \text {, } \\
\text { no increase of Annexin V } \\
\text { labelling }\end{array}$ & {$[62]$} \\
\hline
\end{tabular}

Abbreviations: CAT-catalase; CYP450- cytochrome P450 monooxygenase; dsDNA- double-stranded DNA; GCLC- glutamatecystein ligase, catalytic subunit; GCS- $\gamma$-glutamyl-cysteine synthetase; GST-glutathione-S-transferase; GPx- glutathione peroxidase; GR- glutathione reductase; PCD- programmed cell death; POD- peroxidase; PPB- preprophase band; MFmicrofilament; MT- microtubule; MTOC- microtubule organizing center; MVB- multivesicular body; ROS- reactive oxygen species; SOD- superoxide dismutase.

\section{SUMMARY AND CONCLUDING REMARKS}

We showed many examples on the cytotoxic effects of CYN in eukaryotes/vertebrates in general and human cells in particular (see Table 1 as well). These examples confirm prove that CYN can be a potent genotoxic and cell death inducing toxin, having important implications in human and aquatic ecosystem health. A recent paper points out the importance of CYN depuration for avoiding these health consequences [114]. One should note that CYN toxicity is complex- cell death itself can be triggered by multiple mechanisms- and it is rather difficult to draw a general sequence of events on the cellular effects of CYN. Firstly, the changes induced depend largely on the cell type affected. Secondly, for many cases it is not known whether CYN itself or its metabolites (like deoxycylindrospermopsin or 7epicylindrospermopsin) are responsible for cellular changes or what changes occur in the structure of CYN after its intracellular interaction with CYP450. However, the former two CYN metabolites are believed to give a minor contribution to toxicity $[102,115]$. In spite of the incomplete knowledge on these issues, we are attempting to draw a general scheme of the cellular mechanisms of CYN action in eukaryotes (Fig. 2).

According to the current literature, cellular alterations induced by CYN are likely to be driven by four main mechanisms: (i) inhibition of protein synthesis; (ii) inhibition of pyrimidine nucleotide sythesis; (iii) the induction of ROS and (iv) detachment of ribosomes from RER. These mechanisms are most probably interconnected, however currently we possess very little knowledge on these biochemical connections.

(i) inhibition of protein synthesis is possibly affecting expression of enzymes involved in pyrimidine nucleotide synthesis. Another main target is the cytoskeletal system by decreasing expression of MAPs and subsequent destabilizing mitotic and non-mitotic MT organization. MAPs are known to influence MT stability, bundling, orientation and movement of organelles/macromolecules along the cytoskeleton. Both their levels and post-transcriptional 
modification are important for MT organization [116]. CYN affects cytoskeleton by another mechanism, too- increase of $(\beta-)$ tubulin levels that will affect MTOC functioning in certain organisms. The relevant alterations induced by CYN are proven to induce cell cycle arrest or the delay of mitosis, partially by the induction of abnormal mitosis and chromosome loss, a mechanism that will lead to PCD (Fig. 2.). Cytoskeletal alterations might be related to the induction of ROS - see (iii) below- because they can alter movement of organelles involved in ROS production/scavenging, like mitochondria, peroxisomes and for plants, the chloroplasts [117].

As shown in this review, the protein synthesis inhibitory effect of CYN is a controversial issue, because the cyanotoxin increases, rather than decreases expression of a considerable number of genes not only at transcriptional, but at translational level as well. This raises the question whether CYN interferes with the protein synthesis machinery by interfering with DNA replication and/or transcription through competing with nucleotides during these processes or other mechanisms (see below for example). Thus, further studies are needed to clarify CYN action at the molecular level.

(ii) The inhibition of pyrimidine nucleotide synthesis will certainly affect DNA replication and it is possibly inducing (non-oxidative) DNA damage that will lead to cell cycle arrest and cell death.

(iii) Induction of ROS may be mediated by CYN induced organellar (mitochondrial/chloroplast membrane) and cytoskeletal alterations. ROS will induce oxidative DNA damage that will trigger the activation of p53, subsequently the arrest of cell cycle and finally, cell death.

(iv) CYN induced detachment of ribosomes from RER and alterations in endomembrane (ER, Golgi) organization may induce protein misfolding and gene expression changes on one hand and the formation of MVB/ autophagosomes at the other hand, all these mechanisms leading to cell death.

Fig. (2). Proposed scheme of the subcellular effects of CYN in eukaryotes. Major cyanotoxin induced changes are depicted and dashed arrows indicate the given pathway is not fully elucidated proven or it is hypothetical. Possible alterations driven by cytochrome $\mathrm{P} 450$ monooxygenase (CYP450) mediated metabolic changes are not given here, due to the relatively poor knowledge on this topic. Abbreviations: CDKI- cyclin dependent kinase inhibitor; MT- microtubule, MTOC- microtubule organizing center; MVB- multivesicular body; PCD- programmed cell death. *the given process occurs via yet unknown pathways. Triggering of DNA damage through caspase or caspase-like activities and relationships with endomembrane changes are not shown in this figure, because there is no sufficient evidence for such relationship at CYN treatments.

\section{CONFLICT OF INTEREST}

The authors declare there is no conflict of interest regarding the contents of this article.

\section{REFERENCES}

[1] Ohtani, I.; Moore, R.E.; Runnegar, M.T.C. Cylindrospermopsin: a potent hepatotoxin from the blue-green alga Cylindrospermopsis raciborskii. J. Am. Chem. Soc., 1992, 114, 7941-7942.

[2] Banker, R.; Carmeli, S.; Werman, M.; Teltsch, B.; Porat, R.; Sukenik, A. Uracil moiety is required for toxicity of the cyanobacterial hepatotoxin cylindrospermopsin. J. Toxicol. Environ. Health Part A, 2001, 62, 281-288.

[3] Seifert, M.; McGregor, G.; Eaglesham, G.; Wickramasinghe, W.; Shaw, G. First evidence for the production of cylindrospermopsin and deoxy-cylindrospermopsin by the freshwater benthic cyanobacterium Lyngbya wollei (Farlow ex Gomont) Speziale and Dyck. Harmful Algae, 2007, 6, 73-80.

[4] Banker, R.; Carmeli, S.; Hadas, O.; Teltsch, B.; Porat, R.; Sukenik, A. Identification of cylindrospermopsin in Aphanizomenon ovalisporum (Cyanophyceae) isolated from Lake Kinneret, Israel. J. Phycol., 1997, 33, 613-616.

[5] Preußel, K.; Stuken, A.; Wiedner, C.; Chorus, I.; Fastner, J. First report on cylindrospermopsin producing Aphanizomenon flos-aquae (Cyanobacteria) isolated from two German lakes. Toxicon, 2006, 47, 156-162.

[6] Rücker, J.; Stuken, A.; Nixdorf, B.; Fastner, J.; Chorus, I.; Wiedner, C. Concentrations of particulate and dissolved cylindrospermopsin in 21 Aphanizomenon-dominated temperate lakes. Toxicon, 2007, 50, 800-809.

[7] Kokociński, M.; Mankiewicz-Boczek, J.; Jurczak, T.; Spoof, L.; Meriluoto, J.; Rejmonczyk, E.; Hautala, H.; Vehniäinen, M.; Pawełczyk, J.; Soininen, J. Aphanizomenon gracile (Nostocales), a cylindrospermopsin-producing cyanobacterium in Polish lakes. Environ. Sci. Pollut. Res. Int., 2013, 20, 5243-5264.

[8] Bláhová, L.; Babica, P.; Adamovský, O.; Kohoutek, J.; Maršálek, B.; Bláha, L. Analyses of cyanobacterial toxins (microcystins, cylindrospermopsin) in the reservoirs of the Czech Republic and evaluation of health risks. Environ. Chem. Lett., 2008, 6, 223-227.

[9] Harada, K.; Ohtani, I.; Iwamoto, K.; Suzuki, M.; Watanabe, M.; Terao, K. Isolation of cylindrospermopsin from a cyanobacterium Umezakia natans and its screening method. Toxicon, 1994, 32, 73-84. 
[10] Li, R.; Carmichael, W.W.; Brittain, S.; Eaglesham, G.K.; Shaw, G.R.; Liu, Y.; Watanabe, M.M. First report of the cyanotoxins cylindrospermopsin and deoxycylindrospermopsin from Raphidiopsis curvata (Cyanobacteria). J. Phycol., 2001, 37, 1121-1126.

[11] McGregor, G.B.; Sendall, B.C.; Hunt, L.T.; Eaglesham, G.F. Report of the cyanotoxins cylindrospermopsin and deoxycylindrospermopsin from Raphidiopsis mediterranea Skuja (Cyanobacteria/Nostocales). Harmful Algae, 2011, 10, 402410

[12] Schembri, M.A.; Neilan, B.A.; Saint, C.P. Identification of genes implicated in toxin production in the cyanobacterium Cylindrospermopsis raciborskii. Environ. Toxicol., 2001, 16, 413-421.

[13] Brient, L.; Lengronne, M.; Bormans, M.; Fastner, J. First occurrence of cylindrospermopsin in freshwater in France. Environ. Toxicol., 2009, 24, 415-420.

[14] Spoof, L.; Berg, K.A.; Rapala, J.; Lahti, K.; Lepistö, L.; Metcalf, J.S.; Codd, G.A.; Meriluoto, J. First observation of cylindrospermopsin in Anabaena lapponica isolated from the boreal environment (Finland). Environ. Toxicol., 2006, 21, $552-560$

[15] Mazmouz, R.; Chapuis-Hugon, F.; Mann, S.; Pichon, V.; Mejean, A.; Ploux, O. Biosynthesis of cylindrospermopsin and 7-epicylindrospermopsin in Oscillatoria sp. strain PCC 6506: identification of the cyr gene cluster and toxin analysis. Appl. Environ. Microbiol., 2010, 76, 4943-4949.

[16] Mihali, T.C.; Kellmann, R.; Muenchoff, J.; Barrow, K.D.; Neilan, B.A. Characterization of the gene cluster responsible for cylindrospermopsin biosynthesis. Appl. Environ. Microbiol., 2008, 74, 716-722.

[17] Burgoyne, D.L.; Hemscheidt, T.K.; Moore, R.E.; Runnegar, M.T.C. Biosynthesis of cylindrospermopsin. J. Org. Chem., 2000, 65, 152-156.

[18] Shalev-Alon, G.; Sukenik, A.; Livnah, O.; Schwartz, R.; Kaplan, A. A novel gene encoding amidinotransferase in the cylindrospermopsin producing cyanobacterium Aphanizomenon ovalisporum. FEMS Microbiol. Lett., 2002, 209, 87-91.

[19] Kellmann, R.; Mills, T.; Neilan, B.A. Functional modeling and phylogenetic distribution of putative cylindrospermopsin biosynthesis enzymes. J. Mol. Evol., 2006, 62, 267-280.

[20] Pearson, L.; Mihali, T.; Moffitt, M.; Kellmann, R.; Neilan, B. On the chemistry, toxicology and genetics of the cyanobacterial toxins, microcystin, nodularin, saxitoxin and cylindrospermopsin. Mar. Drugs, 2010, 8, 1650-1680.

[21] Runnegar, M.T.; Xie, C.; Snider, B.B.; Wallace, G.A.; Weinreb, S.M.; Kuhlenkamp, J. In vitro hepatotoxicity of the cyanobacterial alkaloid cylindrospermopsin and related synthetic analogues. Toxicol. Sci., 2002, 67, 81-87.

[22] Bittencourt-Oliveira, M.D.; Piccin-Santos, V.; Moura, A.N.; Aragao-Tavares, N.K.; Cordeiro-Araujo, M.K. Cyanobacteria, microcystins and cylindrospermopsin in public drinking supply reservoirs of Brazil. An. Acad. Bras. Cienc., 2014, 86, 297310 .

[23] Lei, L.; Peng, L.; Huang, X.; Han, B.P. Occurrence and dominance of Cylindrospermopsis raciborskii and dissolved cylindrospermopsin in urban reservoirs used for drinking water supply, South China. Environ. Monit. Assess., 2014, 186, 3079-3090.

[24] Carmichael, W.W.; Azevedo, S.M.; An, J.S.; Molica, R.J.; Jochimsen, E.M.; Lau， S.; Rinehart, K.L.; Shaw, G.R.; Eaglesham, G.K. Human fatalities from cyanobacteria: chemical and biological evidence for cyanotoxins. Environ. Health Perspect., 2001, 109, 663-668.

[25] Griffiths, D.J.; Saker, M.L. The Palm Island mystery disease 20 years on: a review of research on the cyanotoxin cylindrospermopsin. Environ. Toxicol., 2003, 18, 78-93.

[26] Žegura, B.; Štraser, A.; Filipič, M. Genotoxicity and potential carcinogenicity of cyanobacterial toxins- a review. Mutat. Res. -Rev. Mutat., 2011a, 727, 16-41.

[27] de la Cruz, A.A.; Hiskia, A.; Kaloudis, T.; Chernoff, N.; Hill, D.; Antoniou, M.G.; He, X.; Loftin, K.; O'Shea, K.; Zhao, C.; Pelaez, M.; Han, C.; Lynch, T.J.; Dionysiou, D.D. A review on cylindrospermopsin: the global occurrence, detection, toxicity and degradation of a potent cyanotoxin. Environ. Sci.: Processes Impacts, 2013, doi: 10.1039/c3em00353a.

[28] Beyer, D.; Surányi, G; Vasas, G.; Roszik, J.; Erdődi, F.; MHamvas, M.; Bácsi, I.; Bátori, R.; Serfőző, Z.; M. Szigeti, Z.M.; Vereb, G.; Demeter, Z.; Gonda, S.; Máthé, C. Cylindrospermopsin induces alterations of root histology and microtubule organization in common reed (Phragmites australis) plantlets cultured in vitro. Toxicon, 2009, 54, 440449.

[29] Máthé, C.; M-Hamvas, M.; Vasas, G. Microcystin-LR and cylindrospermopsin induced alterations in chromatin organization of plant cells. Mar. Drugs, 2013a, 168, 36893717.

[30] Elliott, C.T.; Redshaw, C.H.; George, S.E.; Campbell, K. First development and characterization of polyclonal and monoclonal antibodies to the emerging fresh water toxin cylindrospermopsin. Harmful Algae, 2013, 24, 10-19.

[31] Gutiérrez-Praena, D.; Risalde, M.A.; Pichardo, S.; Jos, Á.; Moyano, R.; Blanco, A.; Vasconcelos, V.; Cameán, A.M. Histopathological and immunohistochemical analysis of Tilapia (Oreochromis niloticus) exposed to cylindrospermopsin and the effectiveness of $\mathrm{N}$-acetylcysteine to prevent its toxic effects. Toxicon, 2014, 78, 18-34.

[32] Guzmán-Guillén, R.; Gutiérrez-Praena, D.; Risalde, M. de los Á.; Moyano, R.; Prieto, A.I.; Pichardo, S.; Jos, Á.; Vasconcelos, V.; Cameán, A.I. Immunohistochemical approach to study cylindrospermopsin distribution in Tilapia (Oreochromis niloticus) under different exposure conditions. Toxins, 2014, 6, 283-303.

[33] Poniedziałek, B.; Rzymski, P.; Kokociński, M. Cylindrospermopsin: Water-linked potential threat to human 
health in Europe. (review) Environ. Toxicol. Pharmacol. 2012, $34,651-660$.

[34] Norris, R.L.G.; Seawright, A.A.; Shaw, G.R.; Senogles, P.; Eaglesham, G.K.; Smith, M.J.; Chiswell, R.K.; Moore, M.R.; Hepatic xenobiotic metabolism of cylindrospermopsin in vivo in the mouse. Toxicon, 2002, 40, 471-476.

[35] Froscio, S.M.; Humpage, A.R.; Burcham, P.C.; Falconer, I.R. Cylindrospermopsin-induced protein synthesis inhibition and its dissociation from acute toxicity in mouse hepatocytes. Environ. Toxicol., 2003, 18, 243-251.

[36] Kittler, K.; Hurtaud-Pessel, D.; Maul, R.; Kolrep, F.; Fessard, $\mathrm{V}$. In vitro metabolism of the cyanotoxin cylindrospermopsin in HepaRG cells and liver tissue fractions. Toxicon, 2016, 110, 47-50.

[37] Froscio, S.M. Investigation of the mechanisms involved in cylindrospermopsin toxicity: hepatocyte culture and reticulocyte lysate studies. PhD Thesis, Department of Clinical and Experimental Pharmacology, University of Adelaide: Adelaide, March 2002.

[38] Reisner, M.; Carmeli, S.; Werman, M.; Sukenik, A. The cyanobacterial toxin cylindrospermopsin inhibits pyrimidine nucleotide synthesis and alters cholesterol distribution in mice. Toxicol. Sci., 2004, 82, 620-627.

[39] Falconer, I.R.; Humpage, A.R. Preliminary evidence for in vivo tumour initiation by oral administration of oral extracts of the blue-green alga Cylindrospermopsis raciborskii containing the toxin cylindrospermopsin. Environ. Toxicol., 2001, 16, 192-195.

[40] Terao, K.; Ohmori, S.; Igarashi, K.; Ohtani, I.; Watanabe, M.F.; Harada, K.I.; Ito, E.; Watanabe, M. Electron microscopic studies on experimental poisoning in mice induced by cylindrospermopsin isolated from blue-green alga Umezakia natans. Toxicon, 1994, 32, 833-843.

[41] Froscio, S.M.; Humpage, A.R.; Burcham, P.C.; Falconer, I.R. Cell-free protein synthesis inhibition assay for the cyanobacterial toxin cylindrospermopsin. Environ. Toxicol., 2001, 16(5), 408-412.

[42] Xie, C.; Runnegar. M.T.C.; Snider, B.B. Total synthesis of ( \pm ) cylindrospermopsin. J. Am. Chem. Soc., 2000, 122, 5017-5024.

[43] Heintzelman, G.R.; Fang, W.-K.; Keen, S.P., Wallace, G.A.; Weinreb, S.M. Stereoselective total synthesis of the cyanobacterial hepatotoxin 7-epicylindrospermopsin: Revision of the stereochemistry of cylindrospermopsin. J. Am. Chem. Soc., 2001, 123, 8851-8853.

[44] López-Alonso, H.; Rubiolo, J.A.; Vega, F.; Vieytes, M.R.; Botana, L.M. Protein synthesis inhibition and oxidative stress induced by cylindrospermopsin elicit apoptosis in primary rat hepatocite. Chem. Ses., Toxicol., 2013, 26(2), 203-212.

[45] Vasas, G.; Gáspár, A.; Surányi, G.; Batta, G.; Gyémánt, G.; MHamvas, M.; Máthé, C.; Grigorszky, I.; Molnár, E.; Borbély, G. Capillary electrophoretic assay and purification of cylindrospermopsin, a cyanobacterial toxin from
Aphanizomenon ovalisporum, by plant test (blue-green Sinapistest). Anal. Biochem., 2002, 302, 95-103.

[46] Metcalf, J.S.; Barakate, A.; Codd, G.A. Inhibition of plant protein synthesis by the cyanobacterial hepatotoxin, cylindrospermopsin. FEMS Microbiol. Lett., 2004, 235, 125129.

[47] Froscio, S.M.; Humpage, A.R.; Wickramasinghe, W.; Shaw, G.; Falconer, I.R. Interaction of the cyanobacterial toxin cylindrospermopsin with the eukaryotic protein synthesis system. Toxicon, 2008, 51, 191-198.

[48] Rasmussen, J.P.; Froscio, S.M.; Cursaro, M.; Saint, C.P. An examination of the antibiotic effects of cylindrospermopsin on common Gram positive and Gram negative bacteria and the protozoan Naegleria lovaniensis. Environ. Toxicol., 2008, 23(1), 36-43.

[49] Garda, T.; Riba, M.; Vasas, G.; Beyer, D.; M-Hamvas, M.; Hajdu, G.; Tándor, I.; Máthé, C. Cytotoxic effects of cylindrospermopsin in mitotic and non-mitotic Vicia faba cells. Chemosphere, 2015, 120, 145-153.

[50] Gutiérrez-Praena, D.; Pichardo, S.; Jos, Á.; Moreno, F.J.; Cameán, A.M. Alterations observed in the endothelial HUVEC cell line exposed to pure cylindrospermopsin. Chemosphere, 2012c, $89,1151-1160$.

[51] Unuma, T.; Senda, R.; Muramatsu, M. Mechanism of nucleolar segregation- differences in effects of actinomycin D and cycloheximide on nucleoli of rat liver cells. J. Electron Microsc., 1973, 22, 205-216.

[52] Al-Baker, E.; Boyle, J.; Harry, R.; Kill, I.R. A p53independent pathway regulates nucleolar segregation and antigen translocation in response to DNA damage induced by UV irradiation. Exp. Cell Res., 2004, 292, 179-186.

[53] Gutiérrez-Praena, D.; Pichardo, S.; Jos, Á.; Cameán, A.M. Toxicity and glutathione implication in the effects by exposure of the liver fish cell line PLHC-1 to pure cylindrospermopsin. Ecotox. Environ. Safe., 2011b, 74, 1567-1572.

[54] Jámbrik, K.; Máthé, C.; Vasas, G.; Bácsi, I.; Surányi, G.; Gonda, S.; Borbély, G.; M-Hamvas, M. Cylindrospermopsin inhibits growth and modulates protease activity in the aquatic plants Lemna minor L. and Wolffia arrhiza (L.) Horkel. Acta Biol. Hung., 2010, 61, 77-94.

[55] Puerto, M.; Campos, A.; Prieto, A.; Cameán, A.; de Almeida, A.M.; Coelho, A.V.; Vasconcelos, V. Differential protein expression in two bivalve species; Mytilus galloprovincialis and Corbicula fluminea; exposed to Cylindrospermopsis raciborskii cells. Aquat. Toxicol., 2011, 101, 109-116.

[56] Fernández, D.A.; Louzao, M.C.; Vilariño, N.; Fraga, M.; Espiña, B.; Vieytes, M.R.; Botana, L.M. Evaluation of the intestinal permeability and cytotoxic effects of cylindrospermopsin. Toxicon, 2014, 91, 23-34.

[57] Liebel, S.; Grötzner, S.R.; Moura Costa, D.D.; Ferreira Randi, M.A.; de Oliveira Ribeiro, C.A.; Filipak Neto, F. Cylindrospermopsin effects on protein profile of HepG2 cells. 
Toxicology Mech. Methods, 2016, in press, doi: 10.1080/15376516.2016.1216209.

[58] Liebel, S.; de Oliveira Ribeiro, C.A.; Freitas de Magalhães, V.; de Cássio da Silva, R.; Cibere de Rossi, S.; Ferreira Randi, M.A.; Filipak Neto, F. Low concentrations of cylindrospermopsin induce increases of reactive oxygen species levels, metabolism and proliferation in human hepatoma cells (HepG2). Toxicol. In Vitro, 2015, 29, 479-488.

[59] Freitas, M.; Campos, A.; Azevedo, J.; Barreiro, A.; Planchon, S.; Renaut, J.; Vasconcelos, V. Lettuce (Lactuca sativa L.) leaf-proteome profiles after exposure to cylindrospermopsin and a microcystin-LR/cylindrospermopsin mixture: a concentration-dependent response. Phytochemistry, 2015a, 110, 91-103.

[60] Chernoff, N.; Rogers, E.H.; Zehr, R.D.; Gage, M.I.; Malarkey, D.E.; Bradfield, C.A.; Liu, Y.; Schmid, J.E.; Jaskot, R.H., Richards, J.H.; Wood, C.R.; Rosen, M.B. Toxicity and recovery in the pregnant mouse after gestational exposure to the cyanobacterial toxin, cylindrospermopsin. J. Appl. Toxicol., 2011, 31, 242-254.

[61] Štraser, A.; Filipič, M.; Žegura, B. Cylindrospermopsin induced transcriptional changes in human hepatoma HepG2 cells. Toxicol. In Vitro, 2013a, 27, 1809-1819.

[62] Štraser, A.; Filipič, M.; Gorenc, I., Žegura, B. The influence of cylindrospermopsin on oxidative DNA damage and apoptosis induction in HepG2 cells. Chemosphere, 2013b, 92, 24-30.

[63] Runnegar, M.T.; Kong, S.M.; Zhong, Y.K.; Ge, J.L.; Lu, S.C. The role of glutathione in the toxicity of a novel cyanobacterial alkaloid cylindrospermopsin in cultured rat hepatocytes. Biochem. Bioph. Res. Co., 1994, 201, 235-241.

[64] Runnegar, M.T.; Kong, S.M.; Zhong, Y.K.; Lu, S.C. Inhibition of reduced glutathione synthesis by cyanobacterial alkaloid cylindrospermopsin in cultured rat hepatocytes. Biochem. Pharmacol., 1995, 49, 219-225.

[65] Gutiérrez-Praena, D.; Jos, Á.; Pichardo, S.; Cameán, A.M. Oxidative stress responses in tilapia (Oreochromis niloticus) exposed to a single dose of pure cylindrospermopsin under laboratory conditions: influence of exposure route and time of sacrifice. Aquat. Toxicol., 2011a, 105, 100-106.

[66] Falconer, I.R.; Humpage, A.R. Cyanobacterial (blue-green algal) toxins in water supplies: cylindrospermopsins. Environ. Toxicol. 2006, 21, 299-304.

[67] M.-Hamvas, M.; Máthé, C.; Vasas, G.; Jámbrik, K.; Papp, M.; Beyer, D.; Mészáros, I.; Borbély, G. Cylindrospermopsin and microcystin-LR alter the growth, development and peroxidase enzyme activity of white mustard (Sinapis alba L.) seedlings, a comparative analysis. Acta Biol. Hung., 2010, 61, 35-48.

[68] Máthé, C.; Vasas, G.; Borbély, G.; Erdődi, F.; Beyer, D.; Kiss, A.; Surányi, G.; Gonda, S.; Jámbrik, K.; M-Hamvas, M. Histological, cytological and biochemical alterations induced by microcystin-LR and cylindrospermopsin in white mustard (Sinapis alba L.) seedlings. Acta Biol. Hung., 2013b, 64(1), 75-89.
[69] Poniedziałek, B.; Rzymski, P.; Wiktorowicz, K. Toxicity of cylindrospermopsin in human lymphocytes: proliferation, viability and cell cycle studies. Toxicol. In Vitro, 2014, 28, 968-974.

[70] Bain, P.; Shaw, G.; Patel, B. Induction of p53-regulated gene expression in human cell lines exposed to the cyanobacterial toxin cylindrospermopsin. J. Toxicol. Env. Health Part A., 2007, 70, 1687-1693.

[71] Štraser, A.; Filipič, M.; Žegura, B. Genotoxic effects of the cyanobacterial hepatotoxin cylindrospermopsin in the HepG2 cell line. Arch. Toxicol., 2011, 85, 1617-1626.

[72] Gácsi, M.; Antal, O.; Vasas, G.; Máthé, C.; Borbély, G.; Saker, M.L.; Győri, J.; Farkas, A.; Vehovszky, Á.; Bánfalvi, G. Comparative study of cyanotoxins affectiong cytoskeletal and chromatin structures in CHO-K1 cells. Toxicol. In Vitro, 2009, $23,710-718$.

[73] Lankoff, A.; Wojcik, A.; Lisowska, H.; Bialczyk, J.; Dziga, D.; Carmichael, W.W. No induction of structural chromosomal aberrations in cylindrospermopsin-treated CHO-K1 cells without and with metabolic activation. Toxicon, 2007, 50, 1105-1115.

[74] Reid, K.J.; Lang, K.; Froscio, S.; Humpage, A.J.; Young, F.M. Undifferentiated murine embryonic stem cells used to model the effects of the blue-green algal toxin cylindrospermopsin on preimplantation embryonic stem cell differentiation. Toxicon, 2015, 106, 79-88.

[75] Humpage, A.R.; Fenech, M.; Thomas, P.; Falconer, I.R. Micronucleus induction and chromosome loss in transformed human white cells indicate clastogenic and aneugenic action of the cyanobacterial toxin, cylindrospermopsin. Mutat. Res.Gen. Tox. En., 2000, 472, 155-161.

[76] Baskin, T. I. The cytoskeleton. In: Biochemistry and Molecular Biology of Plants; Buchanan, B.B.; Gruissem, W.; Jones, R.L., Eds.; Wiley Blackwell-ASPB: Chichester, UK, 2015; pp. 191238.

[77] Mineyuki, T. The preprophase band of microtubules: its function as a cytokinetic apparatus in higher plants. Int. Rev. Cytol., 1999, 187, 1-49.

[78] Dhonukshe, P.; Mathur, J.; Hülskamp, M.; Gadella, T.W.J. Microtubule plus-ends reveal essential links between intracellular polarization and localized modulation of endocytosis during division-plane establishment in plant cells. BMC Biol., 2005, 3, 11.

[79] Brinkley, B.R.; Cox, S.M.; Pepper, D.A.; Wible, L.; Brenner, S.L.; Pardue, R.L. Tubulin assembly sites and the organization of cytoplasmic microtubules in cultured mammalian cells. $J$. Cell Biol., 1981, 90, 554-562.

[80] Quéméneur, L.; Gerland, L.M.; Flacher, M.; Ffrench, M.; Revillard, J.P.; Genestier, L. Differential control of cell cycle, proliferation, and survival of primary $\mathrm{T}$ lymphocytes by purine and pyrimidine nucleotides. J. Immunol., 2003, 170, 49864995. 
[81] Linke, S.P.; Clarkin, K.C.; Di Leonardo, A.; Tsou, A.; Wahl, G.M. A reversible, p53-dependent G0/G1 cell cycle arrest induced by ribonucleotide depletion in the absence of detectable DNA damage. Gene. Dev., 1996, 10, 934-947.

[82] McKeehan, W.; Hardesty, B. The mechanism of cycloheximide inhibition of protein synthesis in rabbit reticulocytes. Biochem. Biophys. Res. Commun., 1969, 36, 625-630.

[83] Alberts, B.; Johnson, A.; Lewis, J.; Raff, M.; Roberts, K.; Walter, P. From RNA to protein. In: Molecular biology of the cell; Garland Science/Taylor \& Francis Group: NY, USAAbingdon, UK, 2008; pp. 366-400.

[84] Blobel, G. In: Gene Expression, FEBS $11^{\text {th }}$ Meeting, Copenhagen, Clark, B.F.C.; Klenow, H.; Zenthen, J., Eds; Pergamon Press: Oxford-NY-Toronto-Sydney-Paris-Frankfurt, 1977; pp. 99-107.

[85] Gilmore, R.; Mandon, E.C. Understanding integration of $\alpha$ helical membrane proteins: the next steps. Trends. Biochem. Sci., 2012, 37, 303-308.

[83] Gutiérrez-Praena, D.; Pichardo, S.; Jos, Á.; Moreno, F.J.; Cameán, A.M. Biochemical and pathological toxic effects induced by the cyanotoxin cylindrospermopsin, on the human cell line Caco-2. Water Res., 2012a, 46, 1566-1575.

[87] Guzmán-Guillén, R.; Manzano, I.L.; Moreno, I.M.; Prieto Ortega, A.I.; Moyano, R.; Blanco, A.; Cameán, A.M. Cylindrospermopsin induces neurotoxicity in tilapia fish (Oreochromis niloticus) exposed to Aphanizomenon ovalisporum. Aquat. Toxicol., 2015, 161, 17-24.

[88] Gutiérrez-Praena, D.; Jos, Á.; Pichardo, S.; Moyano, S.; Blanco, A.; Monterde, J.G.; Cameán, A. Time-dependent histopathological changes induced in Tilapia (Oreochromis niloticus) after acute exposure to pure cylindrospermopsin by oral and intraperitoneal route. Ecotox. Environ. Safe., 2012b, $76,102-113$.

[89] Zhao, K.; Zhao, G.M.; Wu, D.; Soong, J.; Birk, A.V.; Schiller, P.W.; Szeto, H.H. Cell-permeable peptide antioxidants targeted to inner mitochondrial membrane inhibit mitochondrial swelling, oxidative cell death, and reperfusion injury. J. Biol. Chem., 2004, 279, 34682-34690.

[90] Darios, F.; Corti, O.; Lücking, C:B.; Hampe, C.; Muriel, M.P.; Abbas, N.; Gu, W.J.; Hirsch, E.T.; Rooney, T.; Ruberg, M.; Brice, A. Parkin prevents mitochondrial swelling and cytochrome c release in mitochondria-dependent cell death. Hum. Mol. Genet., 2003, 12, 517-526.

[91] Hawkins, P.R.; Runnegar, M.T.C.; Jackson, A.R.B.; Falconer, I.R. Severe hepatotoxicity caused by the tropical cyanobacterium (blue-green alga) Cylindrospermopsis raciborskii (Woloszynska) Seenaya et Subba Raju isolated from a domestic water supply reservoir. Appl. Environ. Microbiol., 1985, 50, 1292-1295.

[92] Shen, X.; Lam, P.K.S.; Shaw, G.R.; Wickramasinghe, W. Genotoxicity investigation of a cyanobacterial toxin, cylindrospermopsin. Toxicon, 2002, 40, 1499-1501.
[93] Shaw, G.R.; Seawright, A.A.; Moore, M.R.; Lam, P.K.S. Cylindrospermopsin, a cyanobacterial alkaloid: evaluation of its toxicologic activity. Ther. Drug Monit., 2000, 22, 89-92.

[94] Chong, M.W.K.; Wong, B.S.F.; Lam, P.K.S.; Shaw, G.R.; Seawright, A.A. Toxicity and uptake mechanism of cylindrospermopsin and lophyrotomin in primary rat hepatocytes. Toxicon, 2002, 40, 205-211.

[95] Young, F.M.; Micklem, J.; Humpage, A.R. Effects of bluegreen algal toxin cylindrospermopsin $(\mathrm{CYN})$ on human granulosa cells in vitro. Reprod. Toxicol., 2008, 25, 374-380.

[96] Gutiérrez-Praena, D.; Jos, A.; Pichardo, S.; Puerto, M.; Cameán, A.M. Influence of the exposure way and the time of sacrifice on the effects induced by a single dose of pure cylindrospermopsin on the activity and transcription of glutathione peroxidase and glutathione-S-transferase enzymes in tilapia (Oreochromis niloticus). Chemosphere, 2013, 90, 986-992.

[97] Liebel, S.; Oliveira Ribeiro, C.A.; Silva, R.C.; Ramsdorf, W.A.; Cestari, M.M.; Magalhães, V.F.; Garcia, J.R.E.; Esquivel, B.M.; Filipak Neto, F. Cellular responses of Prochilodus lineatus hepatocytes after cylindrospermopsin exposure. Toxicol. In Vitro, 2011, 25, 1493-1500.

[98] Sotton, B.; Domaizon, I.; Anneville, O.; Cattanéo, F.; Guillard, J. Nodularin and cylindrospermopsin: a review of their effects on fish. Rev. Fish Biol. Fisheries, 2015, 25, 1-19.

[99] Žegura, B.; Gajski, G.; Štraser, A.; Garaj-Vrhovac, V. Cylindrospermopsin induced DNA damage and alteration in the expression of genes involved in the response to DNA damage, apoptosis and oxidative stress. Toxicon, 2011b, 58, 471-479.

[100] Fessard, V.; Bernard, C. Cell alterations but no DNA strand breaks induced in vitro by cylindrospermopsin in $\mathrm{CHO} \mathrm{K} 1$ cells. Environ. Toxicol., 2003, 18, 353-359.

[101] Bazin, E.; Huet, S.; Jarry, G.; Le Hégarat, L.; Munday, J.S.; Humpage, A.R.; Fessard, V. Cytotoxic and genotoxic effects of cylindrospermopsin in mice treated by gavage or intraperitoneal injection. Environ. Toxicol., 2012, 27, 277-284.

[102] Guzmán-Guillén, R.; Prieto, A.I.; Vasconcelos, V.M.; Cameán, A.M. Cyanobacterium producing cylindrospermopsin causes oxidative stress at environmentally relevant concentrations in sub-chronically exposed Tilapia (Oreochromis niloticus). Chemosphere, 2013, 90, 1184-1194.

[103] Poniedziałek, B.; Rzymski, P.; Karczewski, J. The role of the enzymatic antioxidant system in cylindrospermopsin-induced toxicity in human lymphocytes. Toxicol. In Vitro, 2015, 29, 926-932

[104] Humpage, A.R.; Falconer, I.R. Oral toxicity of the cyanobacterial toxin cylindrospermopsin in male Swiss albino mice: determination of no observed adverse effect level for deriving a drinking water guideline value. Environ. Toxicol., 2003, 18, 94-103. 
[105] Fastner, J.; Heinze, R.; Humpage, A.R.; Mischke, U.; Eaglesham, G.K.; Chorus, I. Cylindrospermopsin occurrence in two German lakes and preliminary assessment of toxicity and toxin production of Cylindrospermopsis raciborskii (Cyanobacteria) isolates. Toxicon, 2003, 42, 313-321.

[106] Kinnear, S.H.W.; Fabbro, L.D.; Duivenvoorden, L.J. Variable growth responses of water thyme (Hydrilla verticillata) to whole-cell extracts of Cylindrospermopsis raciborskii. Arc. Environ. Contam. Toxicol., 2008, 54, 187-194.

[107] Prieto, A.; Campos, A.; Cameán, A.; Vasconcelos, V. Effects on growth and oxidative stress status of rice plants (Oryza sativa) exposed to two extracts of toxin-producing cyanobacteria (Aphanizomenon ovalisporum and Microcystis aeruginosa). Ecotox. Environ. Saf., 2011, 74, 1973-1980.

[108] Flores-Rojas, N.C.; Esterhuizen-Londt, M.; Pflugmacher, S. Antioxidative stress responses in the floating macrophyte Lemna minor L. with cylindrospermopsin exposure. Aquat. Toxicol., 2015, 169, 188-195.

[109] Sugiura, M.; Takeda, Y.; Waterhouse, P.; Small, I.; Curtin, S.; Millar, T. Nucleic acids. In: Biochemistry and Molecular Biology of Plants; Buchanan, B.B.; Gruissem, W.; Jones, R.L., Eds.; Wiley Blackwell-ASPB: Chichester, UK, 2015; pp. 240288

[110] Bazin, E.; Mourot, A.; Humpage, A.R.; Fessard, V. Genotoxicity of the freshwater cyanotoxin, cylindrospermopsin, in two human cell lines: Caco-2 and HepaRG. Environ. Mol. Mutagen., 2010, 51, 251-259.

[111] Puerto, M.; Jos, Á.; Pichardo, S.; Moyano, R.; Blanco, A.; Cameán, A.M. Acute exposure to pure cylindrospermopsin results in oxidative stress and pathological alterations in tilapia (Oreochromis niloticus). Environ Toxicol., 2014, 29, 371385.

[112] Oliveira, V.R.; Carvalho, G.M.C.; Avila, M.B.; Soares, R.M.; Azevedo, S.M.F.O.; Ferreira, T.S.; Valença, S.S.; Faffe, D.S.; Zin, W.A. Time-dependence of lung injury in mice acutely exposed to cylindrospermopsin. Toxicon, 2012, 60, 764-772.
[113] Freitas, M.; Azevedo, J.; Pinto, E.; Neves, J.; Campos, A.; Vasconcelos, V. Effects of microcystin-LR, cylindrospermopsin and a microcystin-LR/cylindrospermopsin mixture on growth, oxidative stress and mineral content of lettuce plants (Lactuca sativa L.). Ecotox. Environ. Safe., 2015b, 116, 59-67.

[114] Guzmán-Guillén, R.; Prieto Ortega, A.I.; Moreno, I.M.; Ríos, V.; Moyano, R.; Blanco, A.; Vasconcelos, V.; Cameán, A.M. Effects of depuration on histopathological changes in tilapia (Oreochromis niloticus) after exposure to cylindrospermopsin. Environ. Toxicol., 2016, in press, doi: 10.1002/tox.22326.

[115] Banker, R.; Teltsch, B.; Sukenik, A.; Carmeli, S. $7-$ epicylindrospermopsin, a toxic minor metabolite of the cyanobacterium Aphanizomenon ovalisporum from Lake Kinneret, Israel. J. Nat. Prod., 2000, 63, 387-389.

[116] Maiato, H.; Sampaio, P.; Sunkel, C.E. Microtubule-associated proteins and their essential roles during mitosis. Int. Rev. Cytol., 2004, 241, 53-153.

[117] Stamer, K.; Vogel, R.; Thies, E.; Mandelkow, E.; Mandelkow, E.M. Tau blocks transport of organelles, neurofilaments, and APP vesicles in neurons and enhances oxidative stress. J. Cell Biol., 2002, 156, 1051-1063. 